\title{
A Dopamine- and Protein Kinase A-Dependent Mechanism for Network Adaptation in Retinal Ganglion Cells
}

\author{
Cecilia F. Vaquero, Angela Pignatelli, Gloria J. Partida, and Andrew T. Ishida \\ Section of Neurobiology, Physiology, and Behavior, University of California, Davis, California 95616
}

\begin{abstract}
Vertebrates can detect light intensity changes in vastly different photic environments, in part, because postreceptoral neurons undergo "network adaptation." Previous data implicated dopaminergic, cAMP-dependent inhibition of retinal ganglion cells in this process yet left unclear how this occurs and whether this occurs in darkness versus light. To test for light- and dopaminedependent changes in ganglion cell cAMP levels in situ, we immunostained dark- and light-adapted retinas with anti-cAMP antisera in the presence and absence of various dopamine receptor ligands. To test for direct effects of dopamine receptor ligands and membrane-permeable protein kinase ligands on ganglion cell excitability, we recorded spikes from isolated ganglion cells in perforated-patch whole-cell mode before and during application of these agents by microperfusion. Our immunostainings show that light, endogenous dopamine, and exogenous dopamine elevate ganglion cell cAMP levels in situ
\end{abstract}

One of several ways in which vertebrate retinas contribute to vision is to adjust their dynamic range to ambient stimuli. A well known illustration of this is the decline in light sensitivity as mean light levels increase. This adjustment is functionally important because it allows luminance contrast to be detected over a wide range of background light intensities, and because it abates response saturation (Shapley and Enroth-Cugell, 1984). In studies performed over the past 40 years, this adjustment has been found to be complex in at least two respects. First, it is achieved at moderate and bright background intensities by events in more than one population of cells, namely, light adaptation in photoreceptors (Baylor and Hodgkin, 1974) and network adaptation in interneurons and retinal ganglion cells (Barlow and Levick, 1969; Sakmann and Filion, 1972; Green et al., 1975). Second, network adaptation can occur at lower light intensities than does photoreceptor light adaptation (Pirenne, 1958; Sakmann and Filion, 1972; Enroth-Cugell and Shapley, 1973; Green et al., 1975; Ashmore and Falk, 1980), yet it can remain tonically effective, even at brighter intensities, for long periods of time (e.g., hours of daylight).

Modulation of ganglion cell light sensitivity by light that does

Received May 23, 2001; revised Aug. 9, 2001; accepted Aug. 16, 2001.

This work was supported by National Institutes of Health Grant EY08120 (A.T.I.) and National Eye Institute Core Grant P30 EY12576. We thank W. G. Owen, M. Piccolino, and K. H. Britten for comments on this manuscript; A. J. Sillman for use of infra-red image-converting goggles; S. C. Lee for performing the recordings exemplified in Fig. 5e; R. A. Fontanilla for assistance in confocal imaging; and K. E. Munckton for assistance with some of the data analysis.

Correspondence should be addressed to Dr. Andrew Ishida, Section of Neurobiology, Physiology, and Behavior, University of California, 1 Shields Avenue, Davis, CA 95616. E-mail: atishida@ucdavis.edu.

Copyright (C) 2001 Society for Neuroscience $\quad 0270-6474 / 01 / 218624-12 \$ 15.00 / 0$ by activating D1-type dopamine receptors. Our spike recordings show that D1-type agonists and 8-bromo cAMP reduce spike frequency and curtail sustained spike firing and that these effects entail protein kinase A activation. These effects resemble those of background light on ganglion cell responses to light flashes. Network adaptation could thus be produced, to some extent, by dopaminergic modulation of ganglion cell spike generation, a mechanism distinct from modulation of transmitter release onto ganglion cells or of transmitter-gated currents in ganglion cells. Combining these observations with results obtained in studies of photoreceptor, bipolar, and horizontal cells indicates that all three layers of neurons in the retina are equipped with mechanisms for adaptation to ambient light intensity.

Key words: retina; light adaptation; network adaptation; contrast sensitivity; filtering; dopamine; protein kinase $A$

not adapt photoreceptors and by brighter light might result from changes in the release of a neuromodulatory transmitter. Numerous observations indicate that dopamine is this type of transmitter. For example, light stimulates intraretinal dopamine release (Kramer, 1971), exogenous dopamine inhibits ganglion cells in situ (Straschill and Perwein, 1969; Glickman et al., 1982), and depletion or destruction of dopamine-releasing interneurons augments reflex responses to brightness (Häggendahl and Malmfors, 1965; Lin and Yazulla, 1994). Thus, several types of observations together have raised the possibility that light reduces ganglion cell spike firing via dopamine receptor activation.

To date, one study has shown that dopamine can inhibit spiking in dissociated retinal ganglion cells (Liu and Lasater, 1994). This study indicated that dopamine responses entail an elevation of cAMP and concluded that inhibition results from reducing voltage-gated $\mathrm{Ca}^{2+}$ current without affecting voltage-gated $\mathrm{Na}^{+}$ or $\mathrm{K}^{+}$currents. These results were unexpected because previous investigators found that retinal ganglion cell cAMP levels were not changed by dopamine (Young and Dowling, 1989) or by adapting lights (Orr et al., 1976). Moreover, although dopamine activates cAMP-dependent protein kinase (PKA) in various neurons, this kinase does not necessarily produce inhibition by reducing voltage-gated $\mathrm{Ca}^{2+}$ currents (Schiffmann et al., 1995). Below, we reexamine whether light and dopamine augment cAMP levels in retinal ganglion cells. We also test whether dopamine receptor ligands inhibit ganglion cells under conditions that block voltage-gated $\mathrm{Ca}^{2+}$ currents and whether spike inhibition by dopamine entails PKA activation.

Parts of this paper have been published previously in abstract form (Vaquero and Ishida, 2000). 


\section{MATERIALS AND METHODS}

\section{Species}

Goldfish (Carassius auratus; body length, 9-16 cm) were used for this study, because several studies have suggested that their ganglion cells should respond to changes in dopamine release. In particular, dopaminergic neurons extend vesicle-containing processes into the ganglion cell and optic fiber layers (Yazulla and Zucker, 1988), dopamine receptors have been localized in the inner plexiform layer and on ganglion cell somata (Mora-Ferrer et al., 1999), and dopamine release is $\mathrm{Ca}^{2+}$. dependent (Sarthy and Lam, 1979). Fish were obtained from a commercial fish farm (Dutchman Creek, Merced, CA) and maintained outdoors in a 300 gal holding tank without artificial lighting. Fish were killed by cervical-spinal transection and pithed. Eyes were rapidly excised, and retinas were isolated as described below. All animal care and experimental protocols conformed to guidelines of the Animal Use and Care Administrative Advisory Committee of the University of California, Davis.

\section{Light and dark adaptation}

A circadian oscillator can modulate retinal dopamine release (Dubocovich, 1983). Therefore, at least 2 weeks before experiments, fish were transferred to indoor holding tanks so that their exposure to light could be controlled. For nearly all of the experiments reported here, room lights $\left(50 \mu \mathrm{W} / \mathrm{cm}^{2}\right)$ were turned on at 7 A.M. and off at 7 P.M. "Lightadapted" retinas were then dissected under room light at 10 A.M. (i.e., after a $3 \mathrm{hr}$ exposure to room light during actual day). For comparison, some "dark-adapted" retinas were collected at 10 P.M. (i.e., after $3 \mathrm{hr}$ in darkness at actual night). Other dark-adapted retinas were collected from fish that were maintained for $3 \mathrm{hr}$ in a completely darkened tank, after having been transferred there at 10 A.M.

For some experiments, the room lights in the indoor-tank facility were turned on at 1 A.M. and off at 1 P.M. every day for a minimum of 2 weeks. Then, dark-adapted retinas were collected at 4 P.M. (i.e., after 3 $\mathrm{hr}$ in complete darkness at subjective night). For comparison, lightadapted retinas were collected from fish that were transferred to room light at 4 P.M. and allowed to swim freely for $3 \mathrm{hr}$. Results obtained at subjective night were indistinguishable from those obtained at actual night; results obtained during subjective day were indistinguishable from those obtained during actual day. We therefore refer to retinas herein as either dark- or light-adapted, without specifying actual versus subjective time.

After isolation, retinas were either dissociated into suspensions of cells for patch-clamp recordings or processed for immunostaining using the procedures described below. Isolation, dissociation, incubation in pharmacological agents, and aldehyde fixation of dark-adapted retinas were performed entirely under infrared illumination with the aid of infrared image-converting goggles. Light-adapted retinas were isolated and processed under room lighting.

\section{Immunostaining}

Aldehyde fixation. Freshly isolated retinas were either immersed in aldehyde fixative or aldehyde-fixed after incubation in solutions that contained dopamine receptor ligands (see Results). The fixative contained $4 \%$ paraformaldehyde, $5 \%$ sucrose (w/v), and $150 \mu \mathrm{M} \mathrm{CaCl}{ }_{2}$ in PBS (catalog \#10010-031; Life Technologies, Grand Island, NY), pH 7.4. Retinas were fixed for $90 \mathrm{~min}$ at room temperature and then rinsed three times (10 min each) in PBS containing 5\% sucrose and $150 \mu \mathrm{M} \mathrm{CaCl}_{2}$. These retinas were either immunostained and viewed in whole mount or cryosectioned, immunostained, and viewed as transretinal sections.

Frozen sections. Retinas were cryoprotected by immersion in $30 \%$ sucrose for 1-12 hr, cut into pieces no larger than $5 \mathrm{~mm}$ across, transferred to mounting medium [one part Tissue Freezing Medium (Triangle Biomedical Sciences, Durham, NC) plus two parts of $20 \%$ sucrose in PBS], frozen in liquid nitrogen, and sectioned on a cryostat at 8-10 $\mu \mathrm{m}$ thickness. Sections were mounted on Superfrost/Plus slides (Fisher Scientific, Santa Clara, CA), and stored at $-20^{\circ} \mathrm{C}$. The immunostaining protocol was started within a few hours thereafter.

Immunostaining. Sections and whole mounts were rinsed six times (5 min each) in PBS and then incubated for $1 \mathrm{hr}$ in a blocking solution that consisted of PBS supplemented with $10 \%$ normal goat serum and $0.5 \%$ Triton X-100. These sections and whole mounts were incubated overnight at $4^{\circ} \mathrm{C}$ in (1) an affinity-purified rabbit antiserum directed against cAMP (catalog \#116820; Calbiochem-Novabiochem, San Diego, CA); (2) a control (cAMP-preabsorbed) antiserum made by storing a mixture of $200 \mathrm{nM}$ cAMP and the anti-cAMP antiserum for $1 \mathrm{hr}$ at room temperature (Steiner et al., 1972); or (3) a second control antiserum made by storing a mixture of $200 \mathrm{nM}$ cGMP and the anti-cAMP antiserum for $1 \mathrm{hr}$ at room temperature. After 10 5-min rinses in PBS, sections and whole mounts were incubated in a Cy3-conjugated antirabbit IgG (catalog \#111-165-003; Jackson ImmunoResearch, West Grove, PA) for $1 \mathrm{hr}$ in darkness. Finally, sections and whole mounts were rinsed in PBS, covered by FluorSave mounting medium (CalbiochemNovabiochem) and glass coverslips, and imaged on a laser scanning confocal microscope (model TCS-SP; Leica, Deerfield, IL). Primary and secondary antisera were diluted immediately before use to final concentrations of $1: 300$ to $1: 1000$ and 1:300, respectively, in PBS containing 5\% normal goat serum and $0.1 \%$ Triton X-100. Test (anti-cAMP) and control (preincubated) antisera were applied at identical dilutions to sections cut from the same retinas. Pairs of control and test sections (e.g., dark- versus light-adapted, dopamine receptor agonist versus mixture of agonist plus antagonist, etc.) were imaged with identical photomultiplier gains and pinhole diameters. A Z-line slice depth of $580 \mathrm{~nm}$ was routinely used. The Adobe Photoshop (v.5.5) and Illustrator (v.9.0) software systems (Adobe Systems, San Jose, CA) were used to montage digital micrographs.

\section{Current-clamp, voltage-clamp, and data analysis}

Spikes (namely, action potentials) and voltage-gated $\mathrm{Ca}^{2+}$ currents were recorded with a patch-clamp amplifier (Axopatch 1D; Axon Instruments, Union City, CA) in current- and voltage-clamp mode, respectively. Recordings were made from ganglion cells that were dissociated and identified as described previously (Ishida and Cohen, 1988). For reasons stated in Results, cells were dissociated without visible light, under infrared illumination only, from fish kept in darkness for a 3-hr period that commenced with the beginning of the dark phase of their dark/light cycle. Recordings were made within $12 \mathrm{hr}$ after these dissociations.

All recordings were made in perforated-patch mode (Horn and Marty, 1988). To distinguish between perforated- and ruptured-patch mode, Lucifer yellow $\mathrm{CH}$ di-potassium (Aldrich, Milwaukee, WI) was routinely included at $0.2 \mathrm{mg} / \mathrm{ml}$ in the recording electrode solution. After formation of cell-attached mode, formation of perforated-patch mode was signaled by a decrease in access resistance and an increase in capacitive current transient amplitude, with no observable Lucifer fill. Subsequently, applying a brief pulse of suction to the interior of the electrode holder resulted in the formation of ruptured-patch mode, signaled by a further decrease in access resistance, an increase in capacitive current transient amplitude, and a brilliant Lucifer fill. Therefore, after recordings were completed in the present study, cells were examined for dye exclusion under epifluorescence illumination. Cells found then to be Lucifer-filled were not used for any of the measurements reported here.

Patch electrodes were pulled from borosilicate glass capillaries to tip resistances of $5 \mathrm{M} \Omega$. For spike recordings, the tips of these pipettes were filled with "pipette solution" that contained (in mM): $15 \mathrm{NaCl}, 123 \mathrm{KOH}$, $17 \mathrm{KCl}, 0.25 \mathrm{CaCl}_{2}, 2.6 \mathrm{MgCl}_{2}, 1.5$ BAPTA, and 5 HEPES. In some recordings, the concentrations of $\mathrm{NaCl}$ and $\mathrm{CaCl}_{2}$ in the pipette solution were 10 and $1 \mathrm{mM}$, respectively; this made no qualitative difference in the results. The $\mathrm{pH}$ was adjusted to 7.4 with $\mathrm{HCl}$, and the osmolality was adjusted with sucrose to $260 \mathrm{mOsmol} / \mathrm{kg}$. The pipette shanks were filled with this solution after addition at 1:1000 of a solution containing $2 \mathrm{mg}$ amphotericin B (Sigma, St Louis, MO) plus 3 mg Pluronic F-127 (Molecular Probes, Eugene, OR) in $60 \mu \mathrm{l}$ DMSO (Sigma).

The control "bath solution" contained (in $\mathrm{mM}$ ): $110 \mathrm{NaCl}, 3.5 \mathrm{KCl}, 2.5$ $\mathrm{CaCl}_{2}, 1 \mathrm{MgCl}_{2}, 10 \mathrm{D}$-glucose, and 5 HEPES. The $\mathrm{pH}$ was adjusted to 7.4 with $\mathrm{NaOH}$, and the osmolality was adjusted with sucrose to 280 $\mathrm{mOsmol} / \mathrm{kg}$.

Voltage-gated $\mathrm{Ca}^{2+}$ currents were recorded at membrane potentials similar to those traversed during spikes. For this purpose, currents were activated by depolarizations from a holding potential of $-62 \mathrm{mV}$ to test potentials between -40 and $0 \mathrm{mV}$. The pipette solution contained (in mM): $120 \mathrm{CsOH}, 15 \mathrm{NaCH}_{3} \mathrm{SO}_{3}, 0.34 \mathrm{CaCl}_{2}, 2.6 \mathrm{MgCl}_{2}, 1$ EGTA, 5 HEPES. The $\mathrm{pH}$ was adjusted to 7.4 with methanesulfonic acid, the osmolarity was adjusted with sucrose to $284 \mathrm{mOsm}$, and the patchperforating agent was amphotericin $\mathrm{B}$ (included as described above). The bath solution contained (in $\mathrm{mm}$ ): $120 \mathrm{NaCl}, 3 \mathrm{CsCl}, 30$ tetraethylammonium $\mathrm{Cl}, 2.5 \mathrm{CaCl}_{2}, 1 \mathrm{MgCl}_{2}, 10 \mathrm{D}$-glucose, 5 HEPES. The $\mathrm{pH}$ was adjusted to 7.4 with $\mathrm{NaOH}$, and the osmolality was adjusted with sucrose to $300 \mathrm{mOsm}$. Voltage-gated $\mathrm{Ca}^{2+}$ currents were blocked (in currentand voltage-clamp experiments) by decreasing the bath $\mathrm{Ca}^{2+}$ to 0.1 (or 0.2 ) $\mathrm{mm}$ and increasing the $\mathrm{Mg}^{2+}$ concentration to 2.4 (or 3.4) $\mathrm{mm}$ (see 
Results). In these recordings, voltage-gated $\mathrm{Na}^{+}$current was blocked by $1 \mu \mathrm{M}$ tetrodotoxin, and voltage-gated $\mathrm{K}^{+}$currents were blocked by use of $\mathrm{K}^{+}$-free pipette and bath solutions and by inclusion of $30 \mathrm{~mm}$ tetraethylammonium in the bath (Hidaka and Ishida, 1998).

Experiments were performed at room temperature $\left(\sim 23^{\circ} \mathrm{C}\right)$. Current stimulus generation, voltage-jump protocols, data acquisition, and some off-line data analysis were performed with the pClamp system (versions 6.0.3 and 8.1.01; Axon Instruments). Spikes were elicited by constant current pulses, and voltage-gated $\mathrm{Ca}^{2+}$ currents were activated by stepwise depolarizations. To minimize the possibility of current-clamp response variability among different cells caused by differences in resting potential, small holding currents were used to set resting potentials to approximately $-70 \mathrm{mV}$ at the beginning of recordings. Spikes were then collected in control and test solutions without changing these holding currents. Times that elapsed between spikes in individual spike trains were measured with the Mini Analysis Program (v.4.3.2; Synaptosoft Inc., Leonia, NJ). In both current- and voltage-clamp experiments, the patch-clamp amplifier output was analog-filtered by the four-pole Bessel filter of the amplifier $\left(\mathrm{f}_{\mathrm{c}}=2 \mathrm{kHz}\right)$ and digitally sampled at $2-5 \mathrm{kHz}$. The recording chamber was grounded via an agar bridge, and all membrane potentials were corrected for liquid junction potentials attributable to differences between the bath and pipette solution compositions.

\section{Reagents}

Test agents were dissolved in bath solution on the day of each experiment. To minimize oxidation, dopamine was dissolved in bath solution that was supplemented with $1 \mathrm{~mm}$ ascorbic acid and $0.1 \mathrm{~mm}$ EDTA. All other test solutions were prepared by dissolving agents into bath solution without ascorbate or EDTA. Test solutions were applied to cells by U-tube microperfusion (Krishtal and Pidoplichko, 1980); to guard against mechanical artifacts, control spikes were recorded during U-tube microperfusion of the solution that each test agent was dissolved in.

Test agents were obtained from the following sources: dopamine, BAPTA, and ascorbic acid from Sigma; $\mathrm{CaCl}_{2}$ from $\mathrm{BDH}$ Chemicals (Dorset, UK); SCH-23390, SKF-38393, and sulpiride from Research Biochemicals (Natick, MA); cAMP, cGMP, and 8-bromo-cAMP from Calbiochem-Novabiochem; and Rp-5,6-DCl-cBIMPS (5,6-dichloro-1- $\beta$ D-ribof uranosylbenz-imidazole-3', 5' -cyclic monophosphorothioate, Rpisomer) from Biolog Life Science Institute (Bremen, Germany). These compounds were either dissolved in bath or pipette solution, at their final concentration, or they were diluted in these solutions from stock solutions made in water (or ethanol, in the case of sulpiride) at 300-1000 times the final concentration.

\section{RESULTS}

Two sets of data are presented here. The first addresses whether light or dark increases retinal ganglion cell cAMP levels in situ and whether dopamine mediates this effect. The second shows effects of dopamine receptor activation on ganglion cell excitability.

\section{Light elevates cAMP levels in retinal ganglion cells}

Dark- and light-adapted retinas were immunostained with affinity-purified polyclonal antisera directed against cAMP. Dark-adapted retinas were collected from goldfish that were kept in complete darkness for $3 \mathrm{hr}$ during actual night, subjective night, or actual morning (see Materials and Methods). Light-adapted retinas were collected from fish that were allowed to swim freely under room light for $3 \mathrm{hr}$ during actual morning, actual night, or subjective night (see Materials and Methods). Shorter lightadaptation times were not used because our patch-clamp recordings showed that D1 receptor agonists elicit responses in ganglion cells within 1-2 min (see below), and retinas could not be aldehyde-fixed rapidly enough to resolve cAMP changes within such short times. Cells were examined in the pericentral retina midway between the optic disk and retinal perimeter. Each of the immunostaining results described below was confirmed in retinas isolated from a minimum of three fish, unless noted otherwise.

In dark-adapted retinas, cAMP-like immunoreactivity was found in the inner segments of photoreceptors that were cone-like in size and shape (Figs. 1a,d, 2a, 3d). This agreed with previous reports (Farber et al., 1981), and no attempt was made to determine whether subtypes of cones were selectively stained. In the same retinas, cAMP-like immunoreactivity was either absent in retinal ganglion cells (Figs. $1 a, d, 2 b, 3 d$ ) or present in a few ganglion cells (data not shown).

In light-adapted retinas, nearly all of the somata in the ganglion cell layer were stained (Figs. $1 b, c, 2 d, 3 a, 4 a$ ). The stained somata were indistinguishable in diameter $(10-25 \mu \mathrm{m})$ and shape (round- to gourd-shaped) from those filled by retrograde transport of markers injected into the optic nerve (Ishida and Cohen, 1988) and from those immunostained by antibodies directed against a voltage-gated $\mathrm{Na}^{+}$-channel epitope (Yoshikawa et al., 2000). These somata also resembled the ganglion cell somata in which dopamine elevates cAMP (see below). The somata in the ganglion cell layer that did not exhibit cAMP-like immunoreactivity in light-adapted retinas were small in diameter $(<10 \mu \mathrm{m})$, like cells that do not exhibit voltage-gated $\mathrm{Na}^{+}$-channel-like immunoreactivity (Yoshikawa et al., 2000) and like displaced amacrine cell somata (Marc et al., 1990). Where the latter, blood vessels, and axon fascicles were absent, rows of immunostained somata could be seen (Figs. 1b,c, 2d, 3a, 4a). Serial optical sections through flat-mounted retinas showed that adjacent somata in the ganglion cell layer were immunostained without a noticeable bias for size or spatial distribution (Fig. $2 d$ ). These flat mounts, like the vertical sections in Figure 1, also showed that cone inner segments were brightly stained in dark-adapted retinas but not in light-adapted retinas (Fig. 2, compare $a, c$ ), whereas ganglion cells were brightly stained in light-adapted retinas but not in dark-adapted retinas (Fig. 2, compare $b, d$ ).

The immunostaining of photoreceptors and ganglion cells appeared to be cAMP-specific for the following reasons. First, identical staining patterns were obtained with another anti-cAMP antiserum (catalog \#20-CR60; Fitzgerald Industries, Concord, MA) (data not shown). Second, no cells were stained by the anti-cAMP antiserum after it was preincubated with an excess of cAMP (see Materials and Methods) (Fig. 4b, $d, f$ ). Third, exogenous cGMP did not alter the staining pattern (Fig. 4c).

\section{Endogenous and exogenous dopamine elevates cAMP levels in retinal ganglion cells}

Several investigators have reported that light triggers dopamine release from the retina (Kramer, 1971) and that dopamine stimulates retinal cAMP production (Brown and Makman, 1972). Recently, D1-type dopamine receptors have been localized to fish retinal ganglion cell somata (Wagner and Behrens, 1993; MoraFerrer et al., 1999). We therefore tested the possibility that light can elevate ganglion cell cAMP levels by stimulating endogenous dopamine release.

First, light-adapted retinas were cut into pieces and incubated either in control bath solution or in bath solution that contained dopamine receptor antagonists. Incubation of light-adapted retinas in a D1-type receptor antagonist (SCH-23390; $10 \mu \mathrm{M})$ abolished cAMP-like immunoreactivity in ganglion cells (Fig. 3, compare $a, b)$. A D2-type receptor antagonist (sulpiride, $10 \mu \mathrm{M}$ ) did not produce this effect $(n=1)$ (Fig. 3, compare $a, c)$.

Second, dark-adapted retinas were cut into pieces and incubated for $30 \mathrm{~min}$ in either control bath solution or bath solution that contained dopamine (Dearry and Burnside, 1989; Hampson et al., 1992). Divalent cations that are typically used to block synaptic transmission were not added to the incubation media, because certain divalents (notably $\mathrm{Co}^{2+}$ ) have been found to 


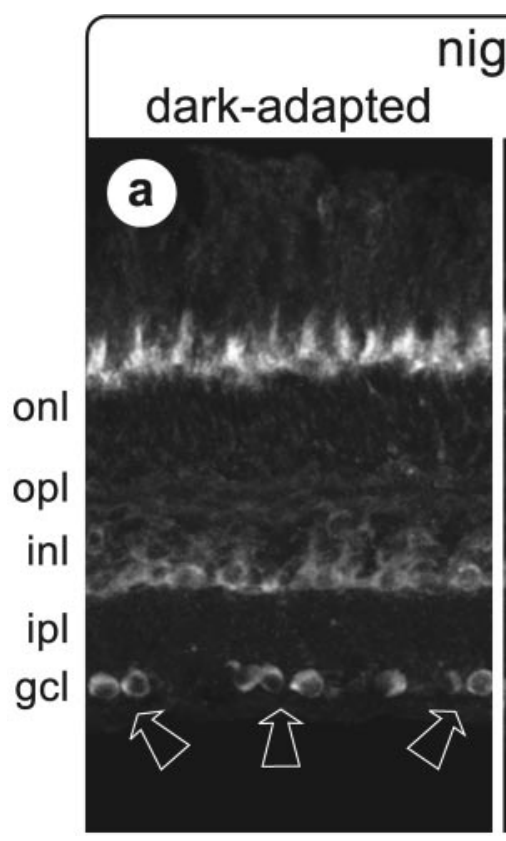

\section{night}

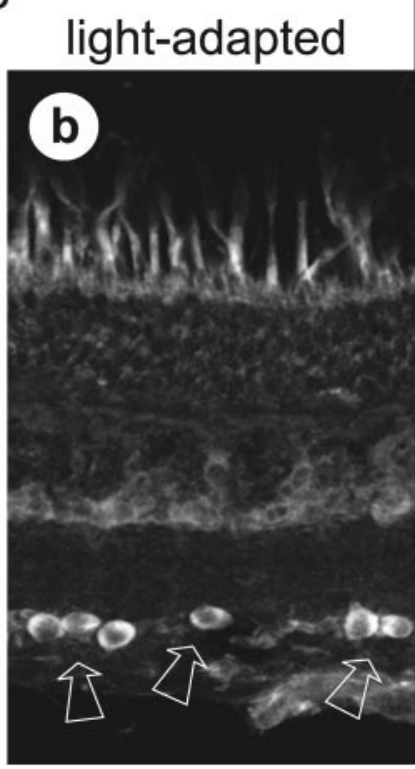

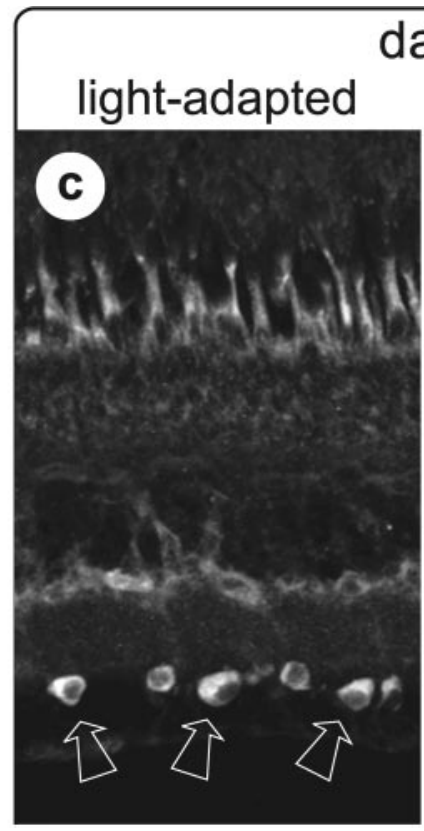

day

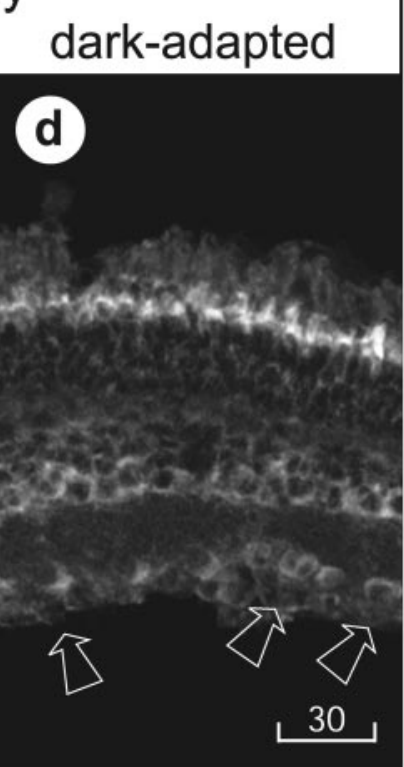

Figure 1. cAMP in light-adapted retinal ganglion cells. Transretinal cryosections were immunostained with anti-cAMP antiserum (1:300 in $a, b ; 1: 1000$ in $c, d)$ and imaged on a laser scanning confocal microscope. Dark-adapted retinas were isolated and fixed under infrared illumination $3 \mathrm{hr}$ after sunset $(a)$ or from fish transferred to complete darkness for a $3 \mathrm{hr}$ period that began $3 \mathrm{hr}$ after sunrise $(d)$. Light-adapted retinas were isolated and fixed under room light $3 \mathrm{hr}$ after sunrise $(c)$ or from fish exposed to room light for a $3 \mathrm{hr}$ period that began $3 \mathrm{hr}$ after sunset $(b)$. The intensity of fluorescence that passed through a $590 \mathrm{~nm}$ long-pass filter was displayed in gray scale in this figure and in Figures 3 and 4, with the brightest fluorescence appearing white. cAMP-like immunoreactivity is most vivid at the level of cone photoreceptor inner segments in dark-adapted retinas and in ganglion cell layer in light-adapted retinas. cAMP-like immunoreactivity in photoreceptors is reduced in light-adapted retinas. Arrows point to some of the ganglion cell somata in each section. Magnification is identical in all panels. onl, Outer nuclear layer; opl, outer plexiform layer; inl, inner nuclear layer; ipl, inner plexiform layer; $g c l$, ganglion cell layer. Scale bar, $30 \mu \mathrm{m}$.

increase retinal neuron responses to dopamine (Cohen, 1982), and because ganglion cell responses to dopamine receptor agonists were studied separately in the absence of synaptic inputs (see below). cAMP-like immunoreactivity was observed in ganglion cells in dark-adapted retinas incubated in $30 \mu \mathrm{M}$ dopamine (Figs. $3 e, f, 4 e$ ). This immunoreactivity resembled that observed in light-adapted retinas (Figs. $1 b, c, 2 d$ ) in terms of the cells that were stained. As in light-adapted retinas that were not treated with dopamine, ganglion cells in dark-adapted, dopamine-treated retinas were not stained by antiserum that was preincubated in cAMP (Fig. $4 f$ ). Moreover, no cAMP-like immunoreactivity was observed in ganglion cells in pieces of dark-adapted retinas that were incubated for $10 \mathrm{~min}$ in $30 \mu \mathrm{M}$ dopamine and then incubated for $20 \mathrm{~min}$ in a mixture of $30 \mu \mathrm{M}$ dopamine and $10 \mu \mathrm{M} \mathrm{SCH}-23390$ (Fig. 3, compare $f, g$ ). This effect is consistent with the block by SCH-23390 of light-induced increases in cAMP immunoreactivity and with effects of SCH-23390 on intracellularly recorded dopamine responses (see below).

In some retinas that were exposed to dopamine, cAMP-like immunoreactivity was observed at the level of cone inner segments (Figs. $3 f, 4 e$ ). This may reflect activation of $\mathrm{D} 1$ receptors that have been detected in fish photoreceptors by binding of SCH-23390 (Wagner and Behrens, 1993), in situ hybridization (Mora-Ferrer et al., 1996), and immunostaining (Mora-Ferrer et al., 1999).

Despite electrophysiological evidence that light elevates cAMP levels in cone-driven horizontal cells (Piccolino et al., 1984), we never observed cAMP-like immunoreactivity in horizontal cells in our preparations, either in dark-adapted retinas that were incubated in dopamine (Figs. 3, 4) or in light-adapted retinas
(Figs. 1, 3, 4). For that matter, we are unaware of any previous immunostaining evidence that light increases cAMP levels in horizontal cells. We have no explanation for this apparent discrepancy. Light-sensitivity and synapse viability were evident in our preparations because light reduced photoreceptor cAMP levels and increased ganglion cell cAMP levels (Figs. 1, 2). We tested the possibility that an avid phosphodiesterase or muted adenylyl cyclase keeps horizontal cell cAMP levels below those in cones and ganglion cells (by incubating retinas in mixtures of dopamine, $10 \mu \mathrm{M}$ forskolin, and either $2 \mathrm{~mm}$ isobutylmethylxanthine or $10 \mathrm{~mm}$ theophylline) (cf. Dowling and Watling, 1981) and still observed no cAMP-like immunoreactivity in horizontal cells. Finally, we did not observe cAMP-like immunoreactivity in horizontal cells in retinas fixed with glutaraldehyde rather than formaldehyde (data not shown).

\section{D1-type receptor activation reduces retinal ganglion cell excitability}

Having found that illumination elevates cAMP levels in retinal ganglion cells and that this response is blocked by a D1-type receptor antagonist, we next tested whether D1-type dopamine receptor activation and elevation of cytoplasmic cAMP affect retinal ganglion cell excitability. These recordings incorporated the following considerations. First, to preclude effects of pharmacological agents on presynaptic cells (Hedden and Dowling, 1978; Shiells and Falk, 1985; Yamada and Saito, 1988; Heidelberger and Matthews, 1994; Maguire and Werblin, 1994; Hare and Owen, 1995) and to preclude the possibility that dopamine effects on homologous or heterologous coupling of ganglion cells (Vaney, 1991) could contribute to the results reported here, we 

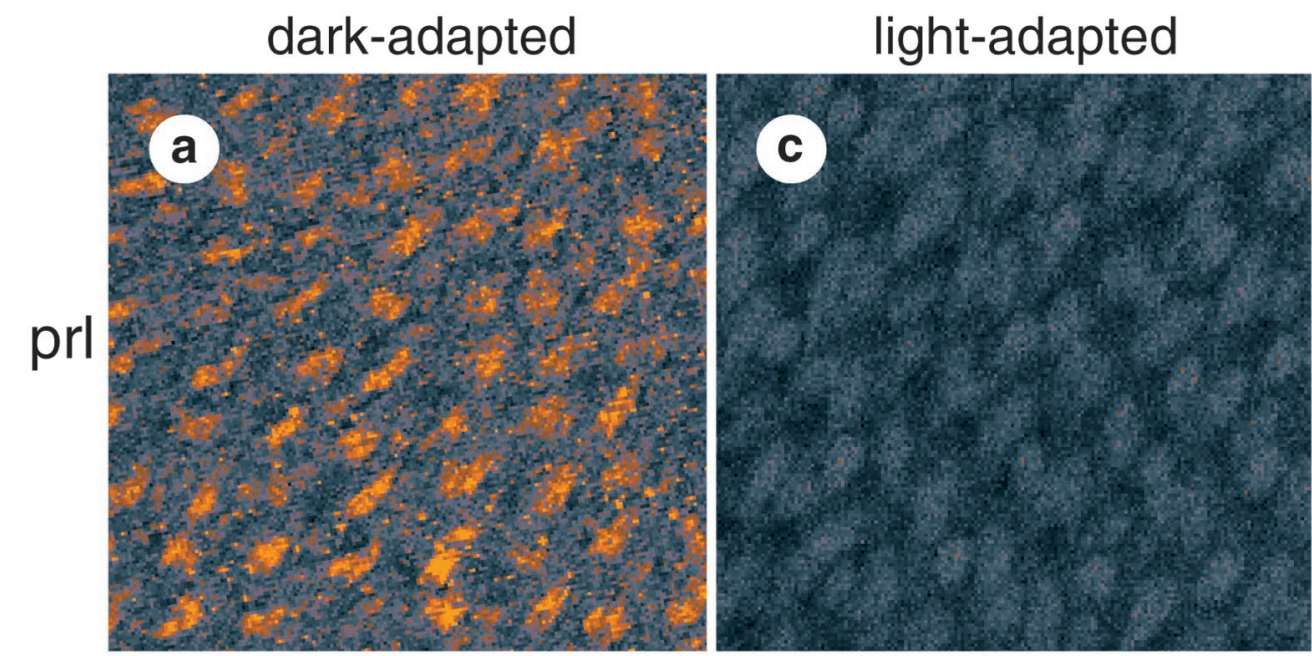

Figure 2. Optical sections through retina of a fully dark-adapted fish $(a, b)$ that was dissected under infrared illumination at $3 \mathrm{hr}$ after sunset and a lightadapted fish $(c, d)$ that was dissected under room light at $3 \mathrm{hr}$ after sunrise. Each retina was fixed and immunostained as in Figure 1, then viewed in flat-mount at different transretinal levels at fixed lateral coordinates. Plane of section is at level of cone inner segments in photoreceptor layer $(\mathrm{prl})$ in $a$ and $c$ and at level of ganglion cell somata $(g c l)$ in $b$ and $d$. The intensity of fluorescence that passed through a 590 $\mathrm{nm}$ long-pass filter was transformed into CMYK color space in this figure, with the dimmest fluorescence appearing light blue and the brightest fluorescence appearing orange. All sections $(a-d)$ were imaged at identical settings of photomultiplier gain and pinhole diameter. Arrows point to some of the ganglion cell somata in $b$ and $d$. A curved row of somata can be seen in $b$, surrounded by the four arrows at the left. Two rows of somata can be seen in $d$, one between the top pair of arrows and the other between the middle pair of arrows. Magnification is identical in all panels. Scale bar, $30 \mu \mathrm{m}$.
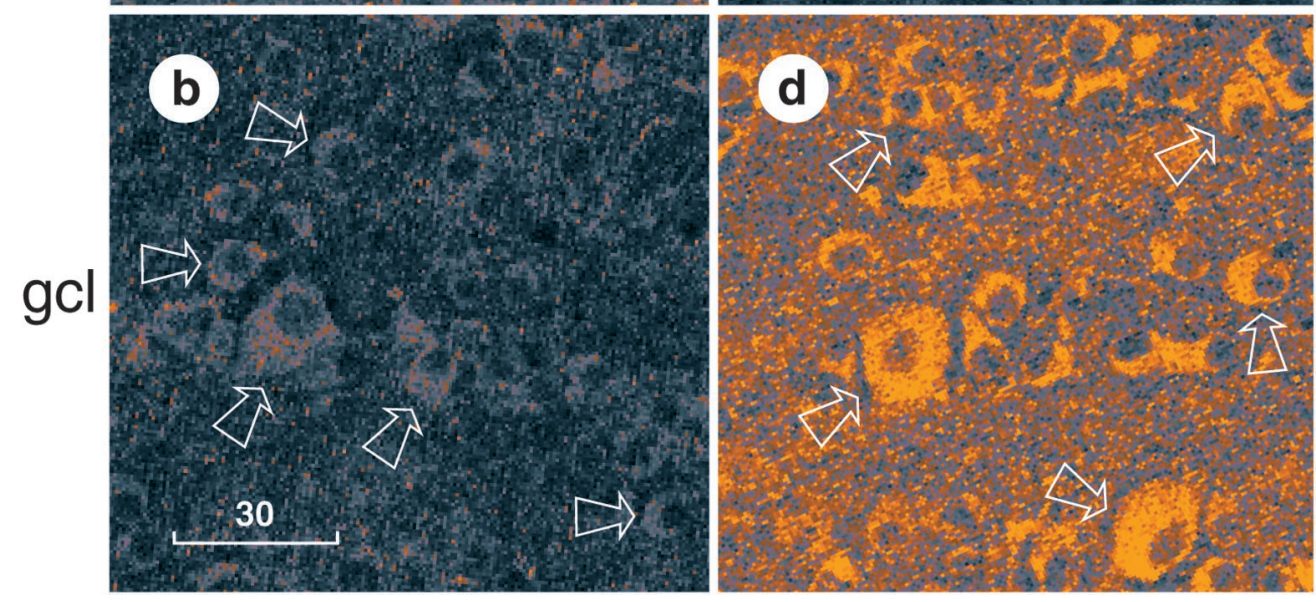

measured the effect of D1-type receptor activation on responses to current injections into isolated ganglion cells (see Materials and Methods). Second, to perform these recordings under conditions identical to those examined by immunostaining above, and thus to minimize variability in spiking and dopamine responses that might arise from light-induced release of endogenous dopamine (or other modulators), all cells were dissociated under infrared illumination, from fish that were kept in complete darkness for $3 \mathrm{hr}$ after the beginning of actual or subjective night (see Materials and Methods and Fig. 1). Third, to preserve secondmessenger cascades and protein kinase activities, all recordings were performed in perforated-patch mode (see Materials and Methods). Finally, because SCH-23390 blocked both light- and dopamine-stimulated cAMP increases in ganglion cells, spikes were recorded before and during application of the D1-type receptor agonist, SKF-38393, and in some cases, dopamine itself.

SKF-38393 (1-30 $\mu \mathrm{M})$ and dopamine $(0.3-3 \mu \mathrm{M})$ abolished spikes elicited by small amounts of exogenous current (Fig. $5 a, b$, compare recordings at left), and reduced the number of spikes elicited by intermediate current intensities (Fig. 5a,b, middle and right). These effects could have been characterized with brief depolarizations if the decrease in spike number resulted only from a decrease in spike frequency. However, cells that spiked continuously during prolonged current injections in control solution failed to spike toward the end of the same current injections during agonist applications (Figs. 5-8), and the "recruitment time" (i.e., the time-to-peak) of the first spike in each train increased (Figs. $5 d, 6 d, 7 d, 8 e$ ). Because control recruitment times as long as $\sim 100$ msec were observed during small current injections, current stimulus durations of $150-500 \mathrm{msec}$ were used to examine spike timing in both control and test solutions. Because only one or two spikes were usually elicited by small and intermediate stimuli in test solutions (Figs. 5-8), spike frequency was calculated from the inverse of the time that elapsed between the first two spikes elicited by each depolarization (Figs. 5-8). Control spike frequencies were calculated in the same way, particularly because control spikes accommodated during the long depolarizing steps used here (Figs. $5 a, 6 a, 7 a, 8 a$ ). To guard against variability caused by jitter, cells were depolarized several times at each stimulus intensity in all solutions, and mean values of the control and test spike latencies and frequencies were compared (Figs. 5-8). Finally, cells were not depolarized more often than once per $4 \mathrm{sec}$ to allow voltage-gated $\mathrm{Na}^{+}$current to recover from inactivation (Hidaka and Ishida, 1998).

As expected from the suppression of spikes at low stimulus intensities and the decrease in spike frequency at other intensities, plots of spike frequency versus stimulus current intensity shifted rightward along the frequency axis during responses to SKF-38393 (Figs. 5, 6, 8) and dopamine (data not shown). At stimulus current intensities that produced a linear increase in spike frequency, these shifts were parallel. For example, the linear regression slopes of intensity-frequency plots before and during application of $1 \mu \mathrm{M} \mathrm{SKF-38393} \mathrm{were} 1.6 \pm 0.1$ and $1.7 \pm 0.2$ $\mathrm{Hz} / \mathrm{pA}$, respectively (mean $\pm \mathrm{SEM} ; n=4$ cells). As expected from the accommodation noted above, these slopes exceed the control slope measured from spike trains elicited in the same cells 


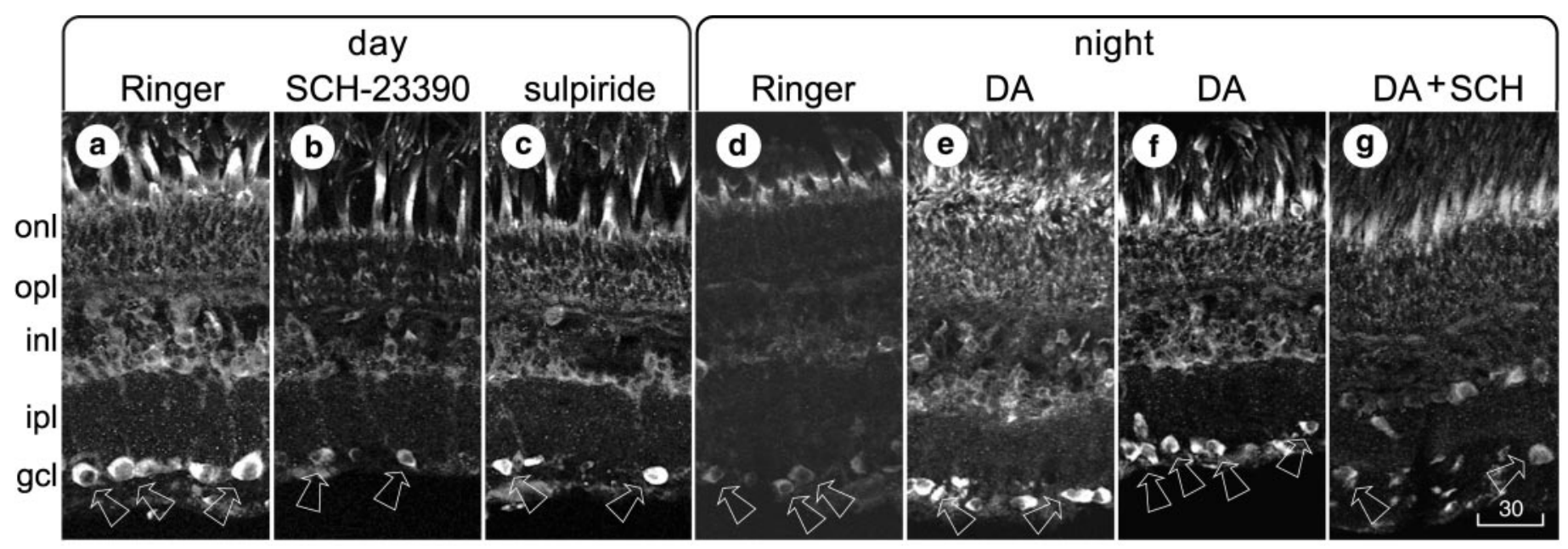

Figure 3. Receptor profile, using retinas that were dark- or light-adapted, then sectioned, processed, and displayed as in Figure 1. $a-c$, Pieces of a single light-adapted retina were incubated for $20 \mathrm{~min}$ in normal Ringer's solution $(a), 10 \mu \mathrm{M} \mathrm{SCH}-23390(b)$, or $10 \mu \mathrm{M}$ sulpiride $(c)$. $d, e$, Pieces of a single dark-adapted retina were incubated for $30 \mathrm{~min}$ in either normal Ringer's solution $(d)$ or $30 \mu \mathrm{M}$ dopamine $(e) . f$, $g$, Pieces of another dark-adapted retina were incubated for $30 \mathrm{~min}$ in $30 \mu \mathrm{M}$ dopamine $(f)$ or for $10 \mathrm{~min}$ in $30 \mu \mathrm{M}$ dopamine, followed by $20 \mathrm{~min}$ in $30 \mu \mathrm{M}$ dopamine plus $10 \mu \mathrm{M} \mathrm{SCH}-23390(g)$. Magnification is identical in all panels. Scale bar, $30 \mu \mathrm{m}$.

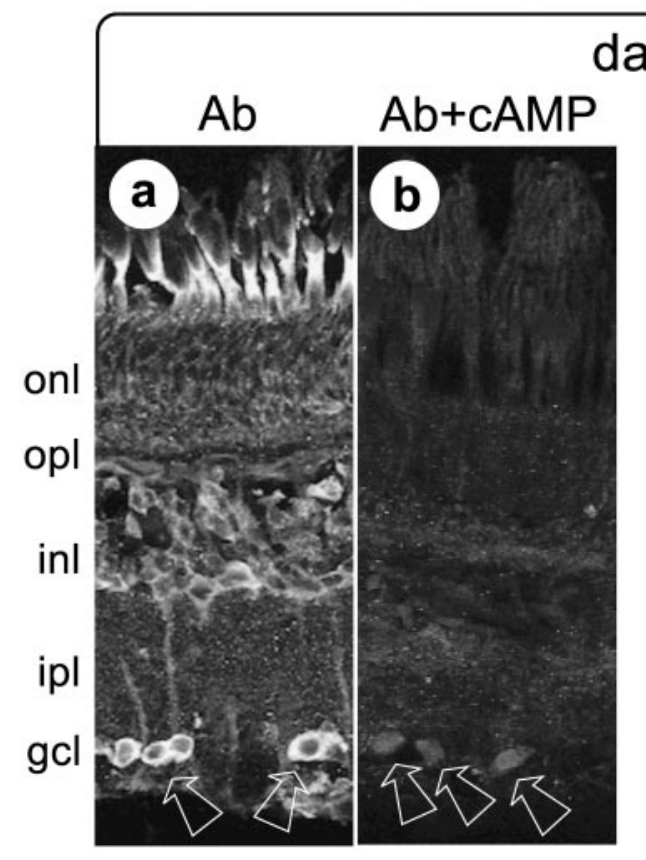

\section{day}
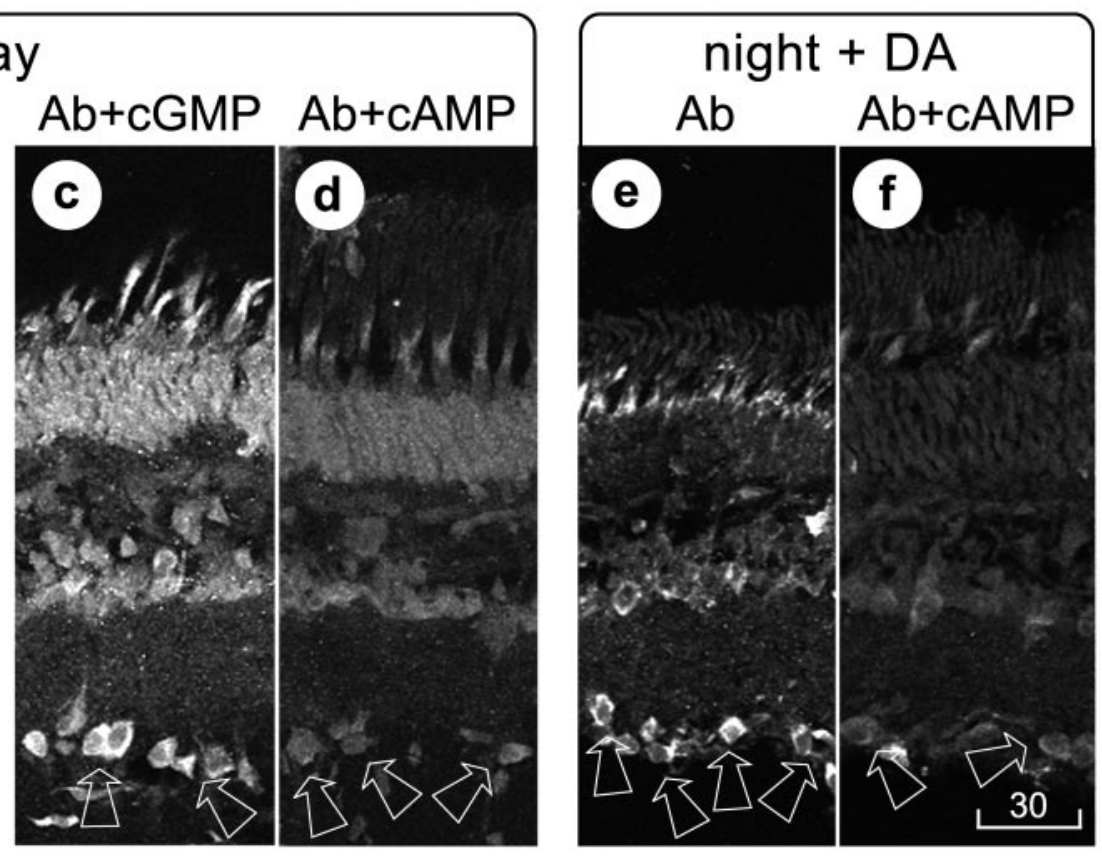

Figure 4. Controls, using retinas that were sectioned, processed, and displayed as in Figure 1. $a, b$, One pair of sections was cut from a light-adapted retina, then incubated with anti-cAMP antiserum $(a)$ or with anti-cAMP antiserum that was preincubated in cAMP $(b)$. $c, d$, Another pair of sections was cut from another light-adapted retina, then incubated with anti-cAMP antiserum that was preincubated in cGMP $(c)$ or with anti-cAMP antiserum that was preincubated in cAMP $(d) . e, f$, A third retina was dark-adapted and incubated for 30 min in darkness in $30 \mu \mathrm{M}$ dopamine. Sections cut from this retina were incubated with anti-cAMP antiserum $(e)$ or with anti-cAMP antiserum that was preincubated in cAMP $(f)$. Magnification is identical in all panels. Scale bar, $30 \mu \mathrm{m}$.

by the long depolarizations $(1.0 \pm 0.2 \mathrm{~Hz} / \mathrm{pA})$. However, the control and test slopes calculated from the pairs of spikes were indistinguishable, and consequently, the response of single cells could be described by the vertical displacement between the control and test linear regressions. For example, $1 \mu \mathrm{M}$ SKF-38393 reduced spike frequency by $7 \pm 2 \mathrm{~Hz}(n=4$; Table 1$)$. In cells firing at a control rate of $40 \mathrm{~Hz}$, this would correspond to an $18 \%$ decrease in spike frequency. D1-type receptor agonists also produced a parallel shift in the intensity-frequency plots of cells that spiked three or more times during step depolarizations in the presence of agonist when spike frequencies were calculated from the mean of the first two interspike intervals activated by each depolarization (data not shown).

Effects of dopamine receptor activation on spike timing were gauged from the times that elapsed between the onset of current injections and the peak of the first spike elicited in control versus test solutions, using the smallest current intensity that activated spikes in the test solution. In saline that contained normal $(2.5$ mм) $\mathrm{Ca}^{2+}, 1 \mu \mathrm{M}$ SKF-38393 increased this latency by $27 \pm 4 \%$ over the control value $(45 \pm 10 \mathrm{msec}$; mean $\pm \mathrm{SEM} ; n=4$; Table 

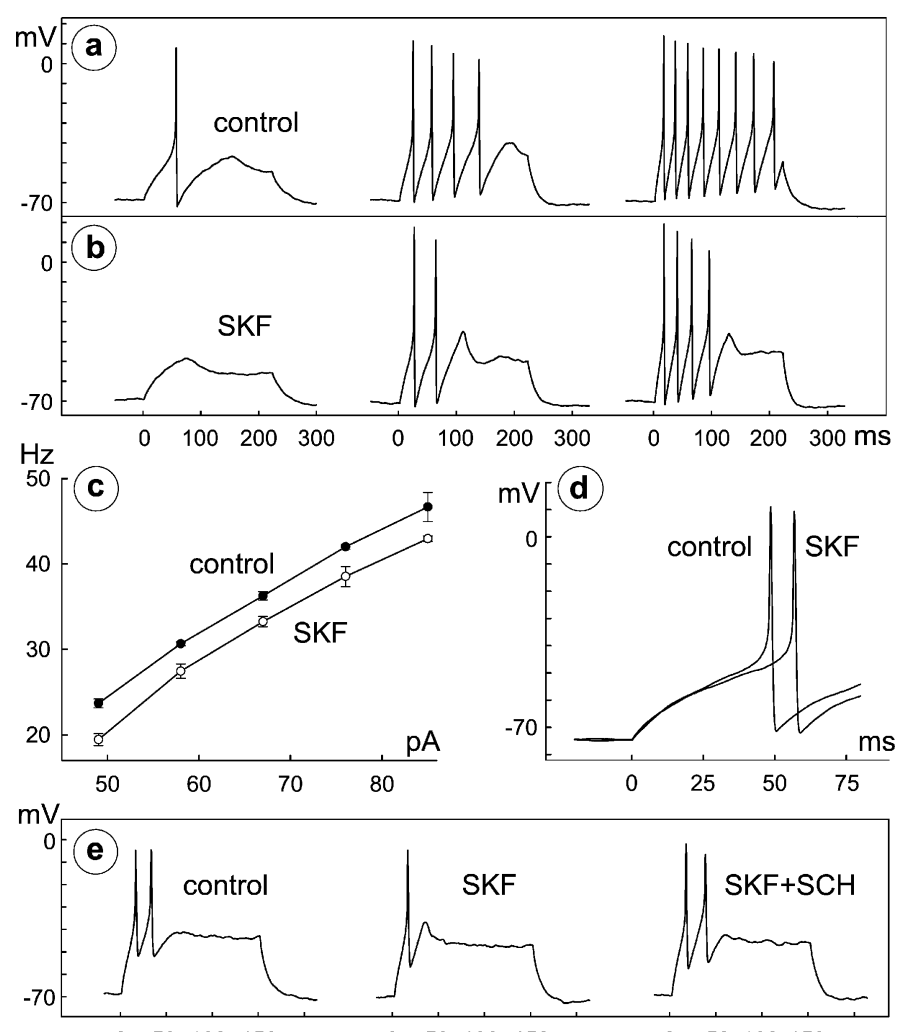

$0 \quad 50100150$

$0 \quad 50100150$

$0 \quad 50100150 \quad \mathrm{~ms}$

Figure 5. Reduction of excitability by D1 receptor agonist. $a, b$, Action potentials were recorded before $(a)$ and during $(b)$ application of $10 \mu \mathrm{M}$ SKF-38393 in bath solution containing $2.5 \mathrm{~mm} \mathrm{Ca}^{2+}$. Spikes fire when cell is depolarized by $225 \mathrm{msec}$ injection of constant current (26, 32, and 35 $\mathrm{pA}$, starting at $t=0 \mathrm{msec}$, in left, middle, and right, respectively). Recordings in each row are displayed with identical $0 \mathrm{mV}$ level; at beginning of traces in both $a$ and $b$, membrane potential is $-71 \mathrm{mV}$. c, Plot of spike frequency (see Results) versus stimulus intensity (pA). Filled and open circles plot mean frequency of control and test spikes, respectively. Error bars indicate \pm SEM. Spike frequencies were not calculated at stimulus intensities that elicited only one spike. $d$, Difference in latency of first spike elicited by injection of $29 \mathrm{pA}$ before and during application of $10 \mu \mathrm{M}$ SKF-38393 (traces labeled control and $S K F$, respectively, superimposed at fast sweep speed). Data in $a-d$ are from one cell. $e$, Block of SKF-38393 response (different cell than $a-d$ ) by D1 receptor antagonist. Spikes were elicited by $150 \mathrm{msec}$ injection of constant current $(55 \mathrm{pA})$ in control solution (left), $3 \mu \mathrm{M}$ SKF-38393 (middle), and $3 \mu \mathrm{M}$ SKF-38393 plus $10 \mu \mathrm{M} \mathrm{SCH}-23390$ (right). These solutions contained $0.2 \mathrm{mM} \mathrm{Ca}{ }^{2+}$ plus $2.4 \mathrm{~mm} \mathrm{Mg}^{2+}$ (compare Fig. 6). Recordings are displayed with identical $0 \mathrm{mV}$ level; membrane potential at beginning of control trace is $-70 \mathrm{mV}$. SCH-23390 alleviates inhibition by SKF-38393.

1). Dopamine agonists produced smaller increases in the latency of spikes elicited by larger stimulus current intensities, and at the largest stimuli used (45-75 pA), no change in latency was noticeable. These agonists thus reduced spike number and frequency at all of the stimulus intensities we used, but they increased spike latency most noticeably during smaller current injections (Fig. $5 d$ ). As discussed below, these changes in spike frequency and firing pattern resemble effects of background light, whereas the increase in latency at low and moderate stimulus intensities does not (see Discussion).

All of the above effects occurred without changes in resting potential (Figs. 5-8). Inhibition was reversible and appeared to be mediated by a D1-type dopamine receptor, because these effects were reversed either by washing away the agonists with agonistfree bath solution (data not shown) or by coapplication of $10 \mu \mathrm{M}$
SCH-23390 (Fig. 5e). Effects of SKF-38393 and dopamine were observed within $\leq 1$ min of the onset of application, and thereafter, for as long as either agonist was applied ( $\leq 14 \mathrm{~min}$ ). Recovery from inhibition occurred within 1-3 min of microperfusing either control bath solution or a mixture of antagonists and agonists onto cells.

Dopamine receptor activation did not increase spike firing in any ganglion cells that we have recorded from. However, the number of cells that we have recorded from successfully (i.e., in which our recordings were stable enough to analyze for this study; $n=14$ ) is smaller than the number of morphological subtypes of ganglion cells that have been identified in various species. If one assumes that the goldfish retina contains 15 different types of retinal ganglion cells (Hitchcock and Easter, 1986), that each type is either inhibited by dopamine or not, and that each type is equally likely to have been recorded from, then our having found that 14 of 14 cells were inhibited by dopamine indicates, with a $p$ value of 0.044 , that at least 13 of these 15 types of ganglion cells are inhibited by dopamine. At the same time, our results do not exclude the possibility that some types of ganglion cells that we have not recorded from might not respond to dopamine or might be excited by dopamine.

\section{$\mathrm{Ca}^{2+}$ current blockade does not prevent inhibition by dopamine}

Dopamine has been found to decrease spike frequency and increase spike latency in cat retinal ganglion cells in situ (Straschill and Perwein, 1969) and in isolated turtle retinal ganglion cells (Liu and Lasater, 1994). These results were obtained in either unperfused eyes or Ringer's solution that contained a normal $\mathrm{Ca}^{2+}$ concentration. It is possible that dopamine alters spiking by affecting $\mathrm{Ca}^{2+}$ influx into these cells (Liu and Lasater, 1994), especially because spike frequency is reduced in retinal ganglion cells by other agents that reduce voltage-gated $\mathrm{Ca}^{2+}$ currents, including $\mathrm{GABA}_{\mathrm{B}}$ receptor agonists, $\mathrm{Co}^{2+}$ and $\mathrm{Cd}^{2+}$, and the Conus toxins $\omega$-MVIIC and $\omega$-GVIA (Liu and Lasater, 1994; Zhang et al., 1997; Rothe et al., 1999). We therefore tested whether D1-type receptor activation inhibits spiking after $\mathrm{Mg}^{2+}$ was substituted for nearly all of the $\mathrm{Ca}^{2+}$ in the bath solution (Fig. 6). This treatment blocks voltage-gated $\mathrm{Ca}^{2+}$ currents in ganglion cells (Fig. 6e), yet retains enough extracellular $\mathrm{Ca}^{2+}$ to avoid undesired effects of $\mathrm{Ca}^{2+}$-free solutions (Almers et al., 1984).

Each of the effects shown in Figure 5, $a-d$, was observed in bath saline that contained $2.4 \mathrm{~mm} \mathrm{Mg}^{2+}$ and either 0.1 or $0.2 \mathrm{~mm}$ $\mathrm{Ca}^{2+}$. SKF-38393 $(10-20 \mu \mathrm{M} ; n=2)$ and dopamine $(0.3 \mu \mathrm{M} ; n=$ 1) abolished spikes produced by small depolarizations (Fig. $6 a, b$ ), truncated repetitive spiking (Fig. $6 b$ ), reduced spike frequency by $17 \pm 4 \mathrm{~Hz}$ (Fig. $6 c$, Table 1), and increased spike latency by $109 \pm$ $58 \%$ over the control value $(32 \pm 8 \mathrm{msec})$ (Fig. $6 d$, Table 1).

\section{8-bromo-cAMP reduces retinal ganglion cell excitability}

Having found that dopamine receptor stimulation augments the concentration of cAMP inside ganglion cells (Figs. 3, 4) and reduces their excitability (Figs. 5, 6, 8), we next tested whether 8-bromo-cAMP reduced ganglion cell excitability. This membrane-permeable cAMP analog produced the same four effects on excitability that were seen during D1-type agonist applications. In saline that contained either $0.2 \mathrm{mM} \mathrm{Ca}^{2+}(n=2)$ or $2.4 \mathrm{mM} \mathrm{Ca}^{2+}(n=2), 100 \mu \mathrm{M} 8$-bromo-cAMP abolished spikes produced by small depolarizations (Fig. $7 b$ ), truncated repetitive 
Table 1. Effect of SKF-38393, dopamine, 8-bromo-cAMP, and Rp-5,6-DCl-cBIMPS on spike frequencies and latencies

\begin{tabular}{|c|c|c|c|c|c|c|c|c|}
\hline \multirow[b]{2}{*}{ Cell number } & \multirow[b]{2}{*}{ Ligand } & \multirow[b]{2}{*}[\mathrm{Ca}^{2+}]{$_{\mathrm{o}}$} & \multicolumn{3}{|c|}{ Spike frequency $(\mathrm{Hz})$} & \multicolumn{3}{|c|}{ Latency to first spike (msec) } \\
\hline & & & Control & Test 1 & Test 2 & Control & Test 1 & Test 2 \\
\hline 313074 & SKF & 2.5 & 40 & 32.7 & & 31.0 & 40.9 & \\
\hline 315019 & SKF & 2.5 & 30 & 19.8 & & 75.8 & 89.6 & \\
\hline 315035 & SKF & 2.5 & 40 & 32.4 & & 35.4 & 43.4 & \\
\hline 316022 & SKF & 2.5 & 40 & 37.2 & & 39.0 & 55.4 & \\
\hline 321028 & SKF & 0.1 & 30 & 13.3 & & 24.9 & 54.1 & \\
\hline 329008 & DA & 0.2 & 60 & 49.9 & & 15.5 & 20.5 & \\
\hline 118018 & SKF & 0.1 & 60 & 35.7 & & 43.5 & 74.0 & \\
\hline 404012 & 8-br-cAMP & 0.2 & 40 & 31.1 & & 58.4 & 83.9 & \\
\hline 416035 & 8-br-cAMP & 0.2 & 40 & 28.2 & & 14.8 & 21.0 & \\
\hline 410016 & 8-br-cAMP & 2.5 & 40 & 34.0 & & 28.5 & 31.4 & \\
\hline 414101 & 8-br-cAMP & 2.5 & 40 & 34.9 & & 49.3 & 61.5 & \\
\hline & & & & & cBIMPS & & & cBIMPS \\
\hline 212017 & SKF & 2.5 & 40 & 30.7 & 35.4 & 32.8 & 38.9 & 33.7 \\
\hline 219071 & SKF & 2.5 & 40 & 35.8 & 38.8 & 34.3 & 41.8 & 34.3 \\
\hline 209165 & SKF & 2.5 & 40 & 30.5 & 35.0 & 20.1 & 28.2 & 20.3 \\
\hline
\end{tabular}

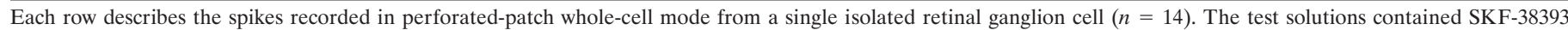

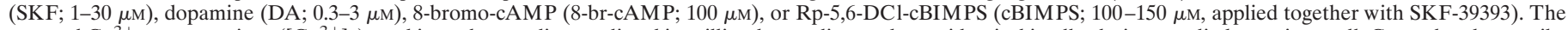

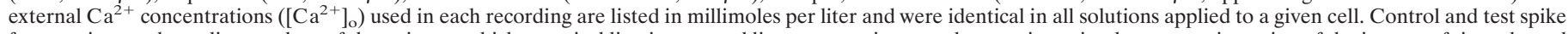

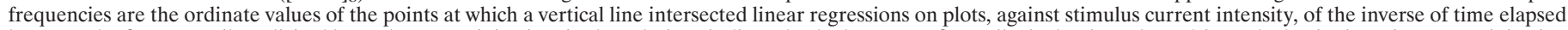

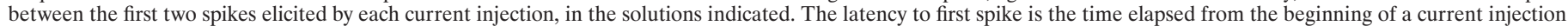

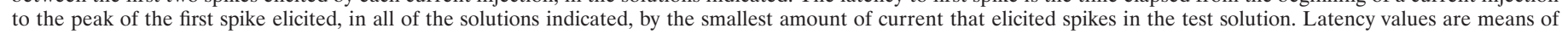
measurements obtained from two to seven identical current injections into each cell in each solution.

spiking (Fig. $7 b$ ), reduced spike frequency by $8 \pm 5 \mathrm{~Hz}$ (Fig. $7 c$, Table 1), and increased spike latency by $30 \pm 8 \%$ over the control value $(38 \pm 10 \mathrm{msec}$ ) (Fig. $7 d$, Table 1$)$. The decrease in spike frequency produced by $100 \mu \mathrm{M}$ 8-bromo-cAMP is similar to that produced by all of the concentrations of SKF-38393 that we tested $(1-30 \mu \mathrm{M})$. Because the above results show that both D1-type dopamine receptor agonists and 8-bromo cAMP inhibit ganglion cells, we did not test whether 8-bromo-cAMP or cAMP activate a cyclic nucleotide-gated inward current in ganglion cells (Ahmad et al., 1994).

\section{Rp-5,6-DCl-cBIMPS blocks inhibition by D1 receptor activation}

Dopamine and cAMP modulate ion currents in various cells via activation of PKA. We therefore tested whether a PKA inhibitor could block ganglion cell responses to D1-type receptor agonists. Figure 8 shows that the reduction of spike frequency, curtailment of repetitive spiking, and increase in spike latency by $30 \mu \mathrm{M}$ SKF-38393 were all counteracted by a membrane-permeable PKA inhibitor (Rp-5,6-DCl-cBIMPS; $100 \mu \mathrm{M}$ ) (Cantrell et al., 1997). Similar effects were observed in all of three cells tested (Table 1). SKF-38393 reduced spike frequency by $8 \pm 2 \mathrm{~Hz}$. During subsequent application of a mixture of SKF-38393 and Rp-5,6-DCl-cBIMPS, spike frequency increased until it differed from the control rate by $4 \pm 1 \mathrm{~Hz}$ (Fig. $8 a-d$, Table 1 ). During the same applications of SKF-38393, spike latency increased to $27 \pm$ $7 \%$ over control values, whereas during the application of SKF38393 together with Rp-5,6-DCl-cBIMPS, spike latency was only $1 \pm 0.8 \%$ longer than the control values (Fig. $8 e$, Table 1 ). These recordings also show that Rp-5,6-DCl-cBIMPS counteracted the effect of D1-receptor activation on repetitive spiking, restoring the number of spikes elicited by a given current injection to control levels (Fig. $8 a-c$ ).

We did not test for effects of PKA inhibitors by inclusion in the pipette solution during ruptured-patch recordings, because cells were unresponsive to D1 receptor agonists in this recording configuration (cf. Horn and Marty, 1988; Vargas et al., 1999).

\section{DISCUSSION}

We have combined immunostaining and spike recording to examine how light sensitivity of the output neurons of the retina is modulated by background illumination. Our results provide the first evidence that light-stimulated release of dopamine raises retinal ganglion cell cAMP levels in situ and that dopaminergic inhibition of these cells can be reversed by a protein kinase A inhibitor. These results imply that ganglion cell spike generation can be modulated by adapting light, by dopaminergic activation of a protein kinase A. Previous studies showed that light adaptation occurs in photoreceptors (Baylor and Hodgkin, 1974), bipolar cells (Ashmore and Falk, 1980), and horizontal cells (Piccolino et al., 1984), i.e., in both tiers of neurons that are distal to ganglion cells. Combining these observations with ours indicates that all three layers of neurons in the retina are equipped with mechanisms for adaptation to ambient light intensity. Below, we discuss how dopaminergic inhibition of ganglion cells may be triggered in situ and how this inhibition compares with that induced by adapting lights.

\section{Light- and dopamine-modulated excitability}

We found that (1) ganglion cell cAMP levels are elevated in fish kept in light during daytime, but not in fish collected in darkness at night; (2) these cAMP levels increase if retinas are illuminated at night, and decrease if retinas are darkened during daytime; (3) exogenous dopamine can elevate ganglion cell cAMP levels in dark-adapted retinas, and this increase can be blocked by $\mathrm{SCH}$ 23390; and (4) SCH-23390 reduces ganglion cell cAMP levels in light-adapted retinas. The simplest explanation of these results is that ganglion cell cAMP levels can be increased by light- 

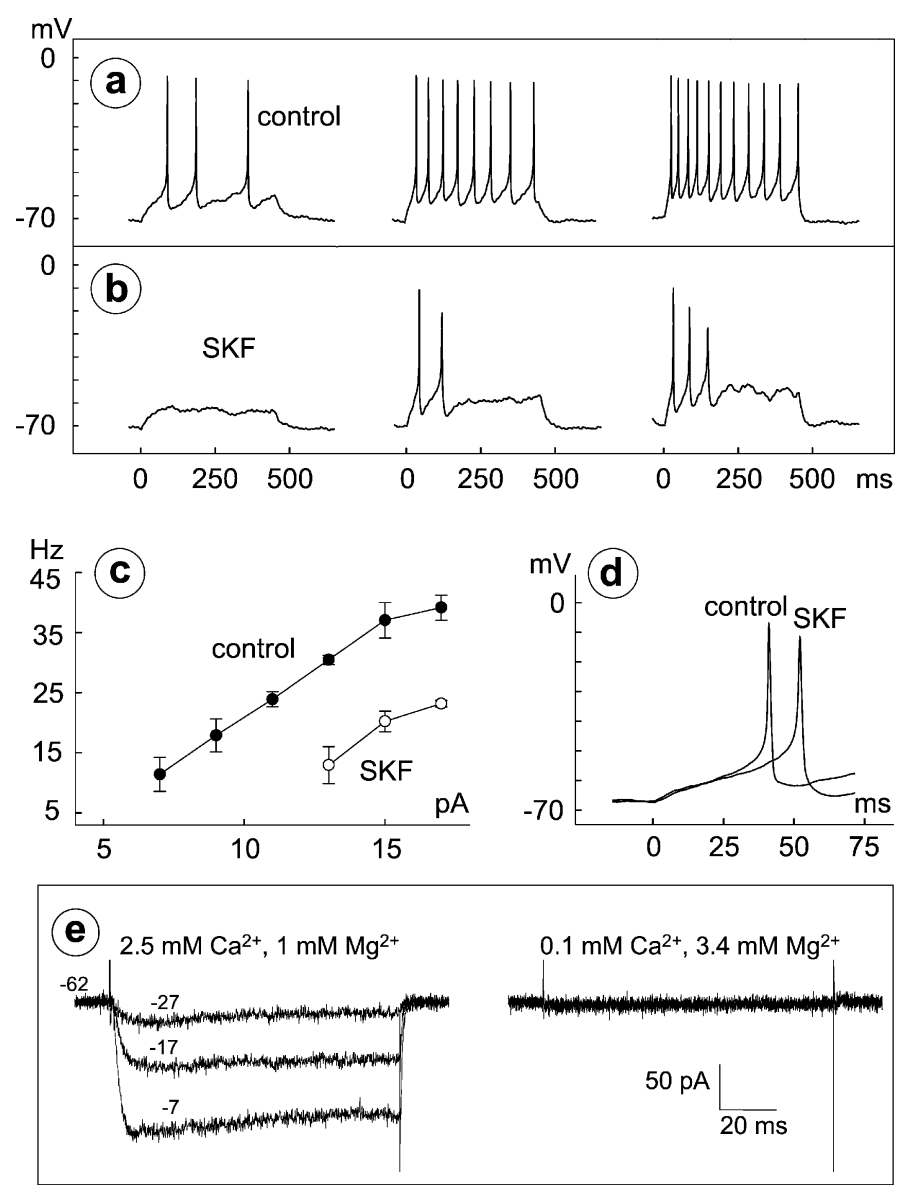

Figure 6. Reduction of excitability in low- $\mathrm{Ca}^{2+}$ saline. $a, b$, Spikes recorded before $(a)$ and during $(b)$ application of $10 \mu \mathrm{M} \mathrm{SKF-38393} \mathrm{in}$ bath solution containing $0.1 \mathrm{mM} \mathrm{Ca}^{2+}$ and $2.4 \mathrm{mM} \mathrm{Mg}^{2+}$. Stimuli are 450 msec, constant-current injections of 7, 11, and $15 \mathrm{pA}$, in left, middle, and right of $a$ and $b$, respectively. Membrane potential at beginning of left trace is $-71 \mathrm{mV}$ in both $a$ and $b$. Intensity-frequency plot $(c)$ and latency of first spikes elicited by injection of $9 \mathrm{pA}$ before and during application of $10 \mu \mathrm{M}$ SKF-38393 (superimposed at fast sweep speed in $d$ ) are from same cell as in $a$ and $b$. Data were formatted as in Figure 5. $e$, Whole-cell current activated by depolarization from a holding potential of $-62 \mathrm{mV}$ to test potentials of $-27,-17$, and $-7 \mathrm{mV}$ in control Ringer's that contained $2.5 \mathrm{mM} \mathrm{Ca}^{2+}$ and $1 \mathrm{mM} \mathrm{Mg}^{2+}$ (left) and in test solution that contained $0.1 \mathrm{mM} \mathrm{Ca}^{2+}$ and $3.4 \mathrm{mM} \mathrm{Mg}^{2+}$ (right). All currents were recorded from same cell (different from that in $a-d$ ) and thus show block of inward current on substitution of $\mathrm{Mg}^{2+}$ for most of the bath $\mathrm{Ca}^{2+}$. Similar results were obtained in five cells in test solution containing 0.1 $\mathrm{mM} \mathrm{Ca}^{2+}$ and $3.4 \mathrm{mM} \mathrm{Mg}^{2+}$ and in four other cells in test solution containing $0.2 \mathrm{mM} \mathrm{Ca}^{2+}$ and $3.4 \mathrm{mM} \mathrm{Mg}^{2+}$.

stimulated dopamine release, regardless of the time of day. In the species studied here, this dopamine would be released by a type of interplexiform cell (Kalloniatis and Marc, 1990).

How does dopamine inhibit spikes in retinal ganglion cells? Our observations that endogenous and exogenous dopamine increase cAMP levels in retinal ganglion cells, that ganglion cell excitability is reduced by dopamine, SKF-38393, and 8-bromocAMP, and that the inhibitory effect of SKF-38393 is counteracted by Rp-5,6-DCl-cBIMPS, together indicate that spiking is inhibited by activation of a D1-type receptor-coupled, cAMPdependent protein kinase (protein kinase A). It is possible that this effect is exerted on voltage-gated $\mathrm{Na}^{+}$currents and/or on voltage-gated $\mathrm{K}^{+}$currents, because similar results were obtained in media that support or block voltage-gated $\mathrm{Ca}^{2+}$ currents,
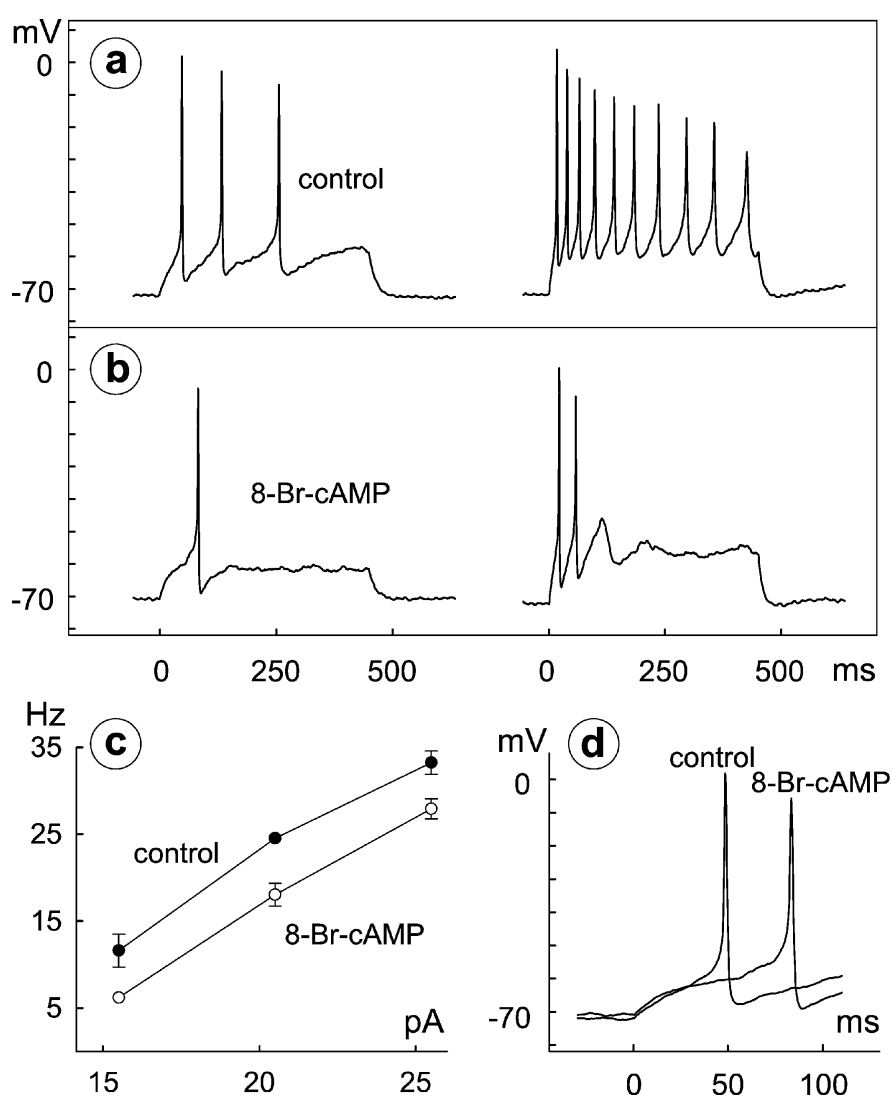

Figure 7. Reduction of excitability by membrane-permeable analog of cAMP. Spikes were recorded before $(a)$ and during $(b)$ application of 100 $\mu \mathrm{M}$ 8-bromo-cAMP in bath solution containing $0.2 \mathrm{mM} \mathrm{Ca}^{2+}$ and $2.4 \mathrm{~mm}$ $\mathrm{Mg}^{2+}$. Stimuli are $450 \mathrm{msec}$, constant-current injections of 15.5 and 30.5 $\mathrm{pA}$ in left and right, respectively, of both $a$ and $b$. Membrane potential is $-72 \mathrm{mV}$ at beginning of left trace in $a$, and $-71 \mathrm{mV}$ in $b$. Intensityfrequency plot $(c)$ and latency of first spikes elicited by injection of 15.5 $\mathrm{pA}$ before and during application of $100 \mu \mathrm{M}$ 8-bromo-cAMP (superimposed at fast sweep speed in $d$ ) from same cell as in $a$ and $b$. Data were formatted as in Figure 5.

inward rectification activates at membrane potentials more negative than those traversed here (Tabata and Ishida, 1996), and the resting $\mathrm{Cl}^{-}$permeability of ganglion cells is controlled by protein kinase C (Tabata and Ishida, 1999). We have not identified which voltage-gated current properties are modulated by dopamine or how protein kinase A activation modulates currents. However, our results show that dopamine can reduce retinal ganglion cell excitability independently of effects on voltage-gated $\mathrm{Ca}^{2+}$ currents (cf. Liu and Lasater, 1994).

Our results also show that dopaminergic inhibition of ganglion cells does not require modulation of the release of, or response to, neurotransmitters. Exogenous dopamine inhibits spontaneous and light-evoked spike firing in ganglion cells in situ, and it can also inhibit spikes elicited by exogenous glutamate (Straschill and Perwein, 1969; Thier and Alder, 1984). This implies that even if dopamine augments the synaptic output of bipolar cells (Heidelberger and Matthews, 1994), the concomitant reduction of retinal ganglion cell excitability would tend to lower spike output.

Our results do not imply that only dopamine modulates ganglion cell excitability or that a single mechanism accounts for network adaptation. For example, dopamine reduces light responses of some on- and off-center bipolar cells (Shiells and Falk, 1985; Hare and Owen, 1995), dopamine and other substances 

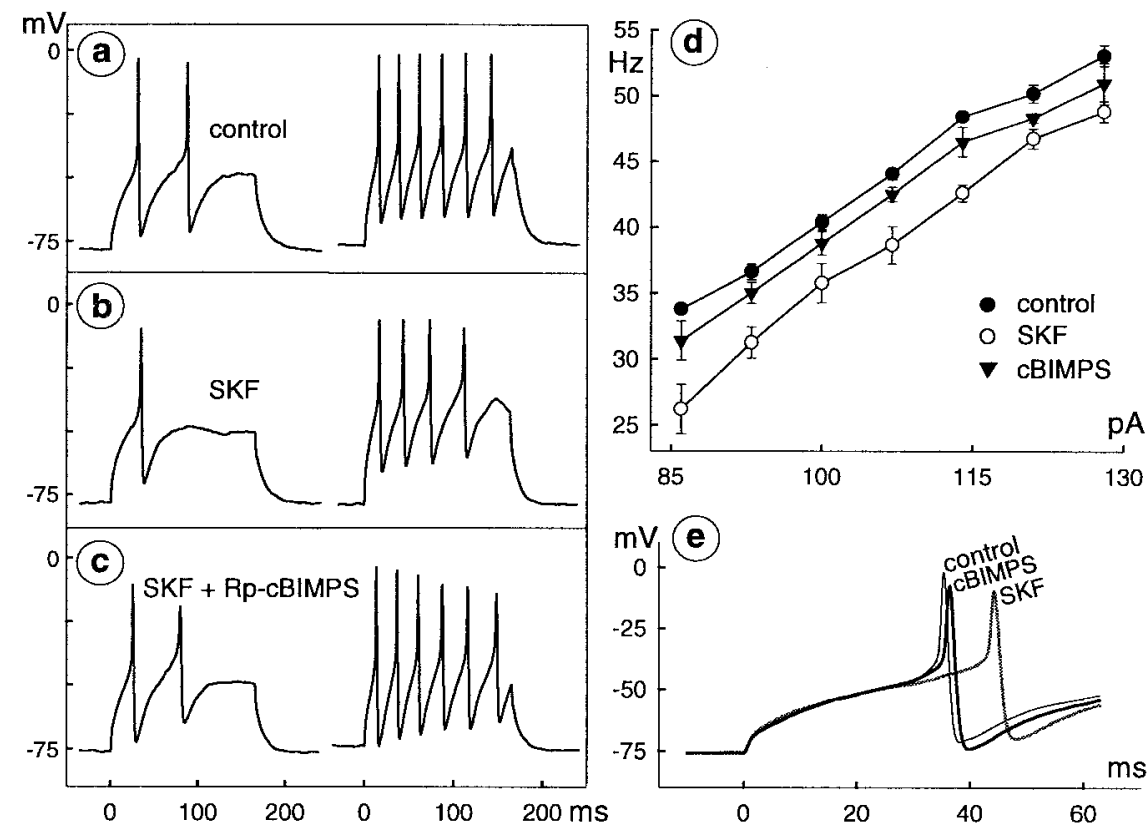

Figure 8. Reversal of D1 agonist response by protein kinase A inhibitor. Spikes were recorded from a single cell before $(a)$ and during $(b)$ application of $30 \mu \mathrm{M}$ SKF-38393, and during (c) subsequent application of a mixture of $30 \mu \mathrm{M}$ SKF-38393 plus $100 \mu \mathrm{M}$ Rp-5,6DCl-cBIMPS. Stimuli are $165 \mathrm{msec}$, constant-current injections of 72 and $107 \mathrm{pA}$ in left and right, respectively, of $a-c$. Membrane potential is $-78 \mathrm{mV}$ at beginning of left trace in $a$ and $b$ and $-77 \mathrm{mV}$ in $c . d$, Intensity-frequency plot with open and filled circles used as in Figures 5-7 and filled triangles plotting data collected during application of SKF-38393 plus Rp5,6-DCl-cBIMPS. $e$, Latency of first spikes elicited by injection of $65 \mathrm{pA}$ in control (thin, black trace), $30 \mu \mathrm{M}$ SKF-38393 (SKF; thick, dark gray trace), and mixture of $30 \mu \mathrm{M}$ SKF-38393 plus $100 \mu \mathrm{M}$ Rp-5,6-DClcBIMPS (cBIMPS; thick, black trace). Records are from same cell as in $a-d$, superimposed at fast sweep speed. Data were formatted as in Figure 5. alter the transmission of rod and cone signals (Witkovsky et al., 1988; Hampson et al., 1992; Mills and Massey, 1995; Wang and Mangel, 1996; Krizaj et al., 1998; Manglapus et al., 1999), fast as well as slow adaptation to a variety of stimuli has been demonstrated in ganglion cells (Enroth-Cugell and Shapley, 1973; Green et al., 1975; Yeh et al., 1996; Smirnakis et al., 1997; Kim and Rieke, 2001), and voltage-induced changes in spike-generation have been shown to underlie temporal contrast adaptation in ganglion cells (Kim and Rieke, 2001).

\section{Adaptation}

Without knowing the effect of dopamine on neurotransmitter release from bipolar and amacrine cells onto ganglion cells or whether dopamine modulates ganglion cell responses to these transmitters, it is difficult to account in detail for ganglion cell light responses under conditions that induce network adaptation. However, if D1 receptor agonists and 8-bromo-cAMP produce effects in ganglion cells that resemble those of background illumination, one would infer that these effects either add to or outweigh those on other cells. How do these compare? First, SKF-38393, dopamine, and 8-bromo-cAMP raise spike threshold, because larger currents are required to elicit individual spikes or a given spike frequency during their application. Likewise, background illumination reduces the number and frequency of spikes that are elicited at different light intensities (Sakmann and Creutzfeld, 1969). This transforms ganglion cells from luminance detectors into contrast detectors (Barlow and Levick, 1969; Sakmann and Creutzfeld, 1969). Various results indicate that this occurs, to some extent, without changes in ganglion cell sensitivity to changes in stimulus current or synaptic input. In particular, we found that D1-type receptor activation and 8-bromo-cAMP produce parallel, rightward shifts in plots of spike frequency versus stimulus current intensity, and likewise, exogenous dopamine (Jensen and Daw, 1986) and background illumination (Sakmann and Creutzfeld, 1969) produce parallel, rightward shifts in plots of spike frequency versus light intensity.

Second, D1-type receptor activation reduced the ability of all of the ganglion cells from which we recorded to spike repeatedly during prolonged depolarizations (Figs. 5, 6, 8). Likewise, back- ground light truncates the spike trains of dark-adapted ganglion cells, transforming sustained cells into transient cells (Yoon, 1972; Jakiela et al., 1976). Thus, background light and D1-type receptor activation filter ganglion cell responses to sustained stimuli. This transforms ganglion cells from low-pass filters (in which spiking is limited by the maximum firing rate) to band-pass filters (in which spiking is damped at low- and high-stimulus frequencies). Our results suggest that this transformation can occur in a relatively simple and unconstrained way. It does not require a change in resting potential as do other mechanisms (Jahnsen and Llinás, 1984; Tabata and Ishida, 1996). Furthermore, although this transformation could occur along with changes in bipolar cell light response and transmitter release kinetics (Richter and Simon, 1975; Kaneko et al., 1979; Diamond and Copenhagen, 1993; Awatramani and Slaughter, 2000) and recruitment of inhibitory receptive field surround input (Barlow et al., 1957; Barlow and Levick, 1969), dopamine could initiate and sustain this transformation (and decrease light sensitivity) without acting through bipolar, horizontal, or amacrine cells.

Third, light augmented cAMP levels in all ganglion cells in a given field of view (Figs. 1-4). This is consistent with the presence of D1-receptor-like immunoreactivity in all ganglion cell somata in the species examined here (Mora-Ferrer et al., 1999), the presence of a dopamine-releasing type of interneuron throughout the retina (Kalloniatis and Marc, 1990), and both paracrine and synaptic transmission (Piccolino et al., 1984; Yazulla and Zucker, 1988; Witkovsky et al., 1993). The staining pattern we have seen is also consistent with the ability of dopamine to right-shift the intensity-response curves of both on- and off-center types of ganglion cells (Jensen and Daw, 1986) and the presence of these cell types throughout the retina (Wässle and Boycott, 1991).

Fourth, ganglion cell cAMP levels were low at night and elevated during the day. This suggests that ganglion cell excitability might wax and wane in a circadian rhythm. Although we have not tested this possibility directly, reflex measurements show that goldfish are more light-sensitive at night than during day (Bassi and Powers, 1987). Moreover, dopamine release can be initiated 
before dawn by a circadian oscillator (Kolbinger et al., 1990). This does not appear to be unique to fish, because mammalian light sensitivity is lower in daytime than at night (Brandenburg et al., 1983), dopamine release is circadian (Dubocovich, 1983), and we have found that anti-cAMP antisera immunostain ganglion cell somata in light-adapted rat retinas (C. F. Vaquero and A. T. Ishida, unpublished observations). It should be noted that our experiments were not designed to test whether cAMP levels were elevated in daylight because they increased in response to the light of dawn or in anticipation of dawn. However, in retinas in which dopamine release continues during the day, network adaptation can be elicited by illumination at night, and dopamine release can be decreased by darkness imposed during the day (Kolbinger et al., 1990; Wang and Mangel, 1996; Manglapus et al., 1999). Our findings that ganglion cell cAMP levels can be elevated by light at night and reduced by darkness during day are thus not at odds with circadian dopamine release.

In summary, we have found that retinal ganglion cells are affected by D1-type receptor activation in ways that mimic background illumination. Our results are consistent with recordings from ganglion cells in intact retinas and with behavioral effects of dopamine depletion. However, unlike background illumination (Pickering, 1968; Enroth-Cugell and Lennie, 1975), dopamine, SKF-38393, and 8-bromo-cAMP increased spike latency (Figs. $5-8)$. We suppose that the spike latency decrease produced by background illumination is attributable, at least in part, to acceleration of photoreceptor and bipolar cell light responses (Baylor and Hodgkin, 1974; Richter and Simon, 1975; Diamond and Copenhagen, 1993; Donner et al., 1995). Examining this aspect of network adaptation and others will require recordings from ganglion cells with intact synaptic inputs and adaptable light responses.

\section{REFERENCES}

Ahmad I, Leinders-Zufall T, Kocsis JD, Shepherd GM, Zufall F, Barnstable CJ (1994) Retinal ganglion cells express a cGMP-gated cation conductance activatable by nitric oxide donors. Neuron 12:155-165.

Almers W, McCleskey EW, Palade PT (1984) A non-selective cation conductance in frog muscle membrane blocked by micromolar external $\mathrm{Ca}^{2+}$ ions. J Physiol (Lond) 353:565-583.

Ashmore JF, Falk G (1980) Responses of rod bipolar cells in the darkadapted retina of the dogfish, Scyliorhinus canicula. J Physiol (Lond) 300:115-150.

Awatramani GB, Slaughter MM (2000) Origin of transient and sustained responses in ganglion cells of the retina. J Neurosci 20:7087-7095.

Barlow HB, Levick WR (1969) Changes in the maintained discharge with adaptation level in the cat retina. J Physiol (Lond) 202:699-718.

Barlow HB, Fitzhugh R, Kuffler SW (1957) Change of organization in the receptive fields of the cat's retina during dark adaptation. J Physiol (Lond) 137:338-354.

Bassi CJ, Powers MK (1987) Circadian rhythm in goldfish visual sensitivity. Invest Ophthalmol Vis Sci 28:1811-1815.

Baylor DA, Hodgkin AL (1974) Changes in time scale and sensitivity of turtle photoreceptors. J Physiol (Lond) 242:729-758.

Brandenburg I, Bobbert AC, Eggelmeyer F (1983) Circadian changes in the response of the rabbit's retina to flashes. Behav Brain Res 7:113-123.

Brown JH, Makman MH (1972) Stimulation by dopamine of adenylate cyclase in retinal homogenates and of adenosine- $3^{\prime}: 5^{\prime}$-cyclic monophosphate formation in intact retina. Proc Natl Acad Sci USA 69:539-543.

Cantrell AR, Smith RD, Goldin AL, Scheuer T, Catterall WA (1997) Dopaminergic modulation of sodium current in hippocampal neurons via cAMP-dependent phosphorylation of specific sites in the sodium channel $\alpha$ subunit. J Neurosci 17:7330-7338.

Cohen AI (1982) Increased levels of $3^{\prime}, 5^{\prime}$-cyclic adenosine monophosphate induced by cobaltous ion or 3-isobutylmethylxanthine in the incubated mouse retina: evidence concerning location and response to ions and light. J Neurochem 38:781-796.

Dearry A, Burnside B (1989) Light-induced dopamine release from teleost retinas acts as a light-adaptive signal to the retinal pigment epithelium. J Neurochem 53:870-878.

Diamond JS, Copenhagen DR (1993) The contribution of NMDA and
non-NMDA receptors to the light-evoked input-output characteristics of retinal ganglion cells. Neuron 11:725-738.

Donner K, Koskelainen A, Djupsund K, Hemilä S (1995) Changes in retina time scale under background light: observations on rods and ganglion cells in the frog retina. Vis Res 35:2255-2266.

Dowling JE, Watling KJ (1981) Dopaminergic mechanisms in the teleost retina. II. Factors affecting the accumulation of cyclic AMP in pieces of intact carp retina. J Neurochem 36:569-579.

Dubocovich ML (1983) Melatonin is a potent modulator of dopamine release in the retina. Nature 306:782-784.

Enroth-Cugell C, Lennie P (1975) The control of retinal ganglion cell discharge by receptive field surrounds. J Physiol (Lond) 247:551-578.

Enroth-Cugell C, Shapley RM (1973) Adaptation and dynamics of cat retinal ganglion cells. J Physiol (Lond) 233:271-309.

Farber DB, Souza DW, Chase DG, Lolley RN (1981) Cyclic nucleotides of cone-dominant retinas. Invest Ophthalmol Vis Sci 20:24-31.

Glickman RD, Adolph AR, Dowling JE (1982) Inner plexiform circuits in the carp retina: effects of cholinergic agonists, GABA, and substance $\mathrm{P}$ on the ganglion cells. Brain Res 234:81-99.

Green DG, Dowling JE, Siegal IM, Ripps H (1975) Retinal mechanisms of visual adaptation in the skate. J Gen Physiol 65:483-502.

Häggendahl J, Malmfors T (1965) Identification and cellular localization of the catecholamines in the retina and the choroid of the rabbit. Acta Physiol Scand 64:58-66.

Hampson EC, Vaney DI, Weiler R (1992) Dopaminergic modulation of gap junction permeability between amacrine cells in mammalian retina. J Neurosci 12:4911-4922.

Hare WA, Owen WG (1995) Similar effects of carbachol and dopamine on neurons in the distal retina of the tiger salamander. Vis Neurosci 12:443-455.

Hedden Jr WL, Dowling JE (1978) The interplexiform cell system. II. Effects of dopamine on goldfish retinal neurones. Proc R Soc Lond B Biol Sci 201:27-55.

Heidelberger R, Matthews G (1994) Dopamine enhances $\mathrm{Ca}^{2+}$ responses in synaptic terminals of retinal bipolar neurons. NeuroReport 5:729-732.

Hidaka S, Ishida AT (1998) Voltage-gated $\mathrm{Na}^{+}$current availability after step- and spike-shaped conditioning depolarizations of retinal ganglion cells. Pflügers Arch 436:497-508.

Hitchcock PF, Easter Jr SS (1986) Retinal ganglion cells in goldfish: a qualitative classification into four morphological types, and a quantitative study of the development of one of them. J Neurosci 6:1037-1060.

Horn R, Marty A (1988) Muscarinic activation of ionic currents measured by a new whole cell recording method. J Gen Physiol 92:145-159.

Ishida AT, Cohen BN (1988) GABA-activated whole-cell currents in isolated retinal ganglion cells. J Neurophysiol 60:381-396.

Jahnsen H, Llinás R (1984) Electrophysiological properties of guineapig thalamic neurones: an in vitro study. J Physiol (Lond) 349:205-226.

Jakiela HG, Enroth-Cugell C, Shapley R (1976) Adaptation and dynamics in X-cells and Y-cells of the cat retina. Exp Brain Res 24:335-342.

Jensen RJ, Daw NW (1986) Effects of dopamine and its agonists and antagonists on the receptive field properties of ganglion cells in the rabbit retina. Neurosci 17:837-855.

Kalloniatis M, Marc RE (1990) Interplexiform cells of the goldfish retina. J Comp Neurol 297:340-358.

Kaneko A, Famiglietti Jr EV, Tachibana M (1979) Physiological and morphological identification of signal pathways in the carp retina. In: Neurobiology of chemical transmission (Otsuka M, Hall Z, eds), pp 235-251. New York: Wiley.

Kim KJ, Rieke F (2001) Temporal contrast adaptation in the input and output signals of salamander retinal ganglion cells. J Neurosci 21:287-299.

Kolbinger W, Kohler K, Oetting H, Weiler R (1990) Endogenous dopamine and cyclic events in the fish retina. I. HPLC assay of total content, release, and metabolic turnover during different light/dark cycles. Vis Neurosci 5:143-149.

Kramer SG (1971) Dopamine: a retinal neurotransmitter. I. Retinal uptake, storage, and light-stimulated release of $\mathrm{H} 3$-dopamine in vivo. Invest Ophthalmol 10:438-452.

Krishtal OA, Pidoplichko VI (1980) A receptor for protons in the nerve cell membrane. Neuroscience 5:2325-2327.

Krizaj D, Gabriel R, Owen WG, Witkovsky P (1998) Dopamine D2 receptor-mediated modulation of rod-cone coupling in the Xenopus retina. J Comp Neurol 398:529-538.

Lin Z-S, Yazulla S (1994) Depletion of retinal dopamine increases brightness perception in goldfish. Vis Neurosci 11:683-693.

Liu Y, Lasater EM (1994) Calcium currents in turtle retinal ganglion cells. II. Dopamine modulation via a cyclic AMP-dependent mechanism. J Neurophysiol 71:743-752.

Maguire G, Werblin F (1994) Dopamine enhances a glutamate-gated ionic current in OFF bipolar cells of the tiger salamander retina. J Neurosci 14:6094-6101.

Manglapus MK, Iuvone PM, Underwood H, Pierce ME, Barlow RB (1999) Dopamine mediates circadian rhythms of rod-cone dominance in the Japanese quail retina. J Neurosci 19:4132-4141. 
Marc RE, Liu W-L, Kalloniatis M, Raiguel SF, Van Haesendonck E (1990) Patterns of glutamate immunoreactivity in the goldfish retina. J Neurosci 10:4006-4034.

Mills SL, Massey SC (1995) Differential properties of two gap junctional pathways made by AII amacrine cells. Nature 377:734-737.

Mora-Ferrer C, Dabin I, Stell WK (1996) In situ hybridization of retinal dopamine D1 receptor in goldfish. Invest Ophthalmol Vis Sci 37:951S.

Mora-Ferrer C, Yazulla S, Studholme KM, Haak-Frendscho M (1999) Dopamine D1-receptor immunolocalization in goldfish retina. J Comp Neurol 411:705-714.

Orr HT, Lowry OH, Cohen AI, Ferrendelli JA (1976) Distribution of $3^{\prime}: 5^{\prime}$-cyclic AMP and $3^{\prime}: 5^{\prime}$-cyclic GMP in rabbit retina in vivo: Selective effects of dark and light adaptation and ischemia. Proc Natl Acad Sci USA 73:4442-4445.

Piccolino M, Neyton J, Gerschenfeld HM (1984) Decrease of gap junction permeability induced by dopamine and cyclic adenosine $3^{\prime}: 5^{\prime}$ monophosphate in horizontal cells of turtle retina. J Neurosci 4:2477-2488.

Pickering SG (1968) The extremely long latency response from on-off retinal ganglion cells: relationship to dark adaptation. Vision Res 8:383-387.

Pirenne MH (1958) Some aspects of the sensitivity of the eye. Ann NY Acad Sci 74:377-384.

Richter A, Simon EJ (1975) Properties of centre-hyperpolarizing, redsensitive bipolar cells in the turtle retina. J Physiol (Lond) 248:317-334.

Rothe T, Jüttner R, Bähring R, Grantyn R (1999) Ion conductances related to development of repetitive firing in mouse retinal ganglion neurons in situ. J Neurobiol 38:191-206.

Sakmann B, Creutzfeld O (1969) Scotopic and mesopic light adaptation in the cat's retina. Pflügers Arch 313:168-185.

Sakmann B, Filion M (1972) Light adaptation of the late receptor potential in the cat retina. In: The visual system. Neurophysiology, biophysics, and their clinical applications. (Arden GB, ed), pp 87-93. New York: Plenum.

Sarthy PV, Lam DMK (1979) The uptake and release of $\left[{ }^{3} \mathrm{H}\right]$ dopamine in the goldfish retina. J Neurochem 32:1269-1277.

Schiffmann SN, Lledo P-M, Vincent J-D (1995) Dopamine D1 receptor modulates voltage-gated sodium current in rat striatal neurones through a protein kinase A. J Physiol (Lond) 483:95-107.

Shapley R, Enroth-Cugell C (1984) Visual adaptation and retinal gain controls. Prog Ret Res 3:263-346.

Shiells RA, Falk G (1985) Dopamine hyperpolarizes and reduces the light responses of rod on-center bipolar cells in the retina of the dogfish. Neurosci Lett 55:331-336.

Smirnakis SM, Berry MJ, Warland DK, Bialek W, Meister M (1997) Adaptation of retinal processing to image contrast and spatial scale. Nature 386:69-73.

Steiner AL, Parker CW, Kipnis DM (1972) Radioimmunoassay for cyclic nucleotides. I. Preparation of antibodies and iodinated cyclic nucleotides. J Biol Chem 247:1106-1113.
Straschill M, Perwein J (1969) The inhibition of retinal ganglion cells by catecholamines and $\gamma$-aminobutyric acid. Pflügers Arch 312:45-54.

Tabata T, Ishida AT (1996) Transient and sustained depolarization of retinal ganglion cells by $\mathrm{I}_{\mathrm{h}}$. J Neurophysiol 75:1932-1944.

Tabata T, Ishida AT (1999) A zinc-dependent $\mathrm{Cl}^{-}$current in neuronal somata. J Neurosci 19:5195-5204.

Thier P, Alder V (1984) Action of iontophoretically applied dopamine on cat retinal ganglion cells. Brain Res 292:109-121.

Vaney DI (1991) Many diverse types of retinal neurons show tracer coupling when injected with biocytin or neurobiotin. Neurosci Lett 125:187-190.

Vaquero CF, Ishida AT (2000) Endogenous dopamine increases cAMP levels in fish retinal ganglion cells in daylight, but not at night. Invest Ophthalmol Vis Sci 41:936.

Vargas G, Yeh T-YJ, Blumenthal DK, Lucero MT (1999) Common components of patch-clamp internal recording solutions can significantly affect protein kinase A activity. Brain Res 828:169-173.

Wagner H-J, Behrens UD (1993) Microanatomy of the dopaminergic system in the rainbow trout retina. Vision Res 33:1345-1358.

Wang Y, Mangel SC (1996) A circadian clock regulates rod and cone input to fish retinal cone horizontal cells. Proc Natl Acad Sci USA 93:4655-4660.

Wässle H, Boycott BB (1991) Functional architecture of the mammalian retina. Physiol Rev 71:447-480.

Witkovsky P, Stone S, Besharse JC (1988) Dopamine modifies the balance of rod and cone inputs to horizontal cells of the Xenopus retina. Brain Res 449:332-336.

Witkovsky P, Nicholson C, Rice ME, Bohmaker K, Meller E (1993) Extracellular dopamine concentration in the retina of the clawed frog, Xenopus laevis. Proc Natl Acad Sci USA 90:5667-5671.

Yamada M, Saito T (1988) Effects of dopamine on bipolar cells in the carp retina. Biomed Res [Suppl] 9:125-130.

Yazulla S, Zucker CL (1988) Synaptic organization of dopaminergic interplexiform cells in the goldfish retina. Vis Neurosci 1:13-29.

Yeh T, Lee BB, Kremers J (1996) The time course of adaptation in macaque retinal ganglion cells. Vision Res 36:913-931.

Yoon M (1972) Influence of adaptation level on response pattern and sensitivity of ganglion cells in the cat's retina. J Physiol (Lond) 221:93-104.

Yoshikawa M, Anderson K, Sakaguchi H, Flannery J, FitzGerald P, Ishida AT (2000) Voltage-gated $\mathrm{Na}^{+}$channel EOIII-segment-like immunoreactivity in fish retinal ganglion cells. Vis Neurosci 17:647-655.

Young LHY, Dowling JE (1989) Localization of cyclic adenosine monophosphate in the teleost retina: effects of dopamine and prolonged darkness. Brain Res 504:57-63.

Zhang J, Shen W, Slaughter MM (1997) Two metabotropic $\gamma$-aminobutyric acid receptors differentially modulate calcium currents in retinal ganglion cells. J Gen Physiol 110:45-58. 